Review

\title{
Strategies of Nanomaterial Application for Enhanced Wound Curing: An Overview
}

\author{
Moupriya Nag ${ }^{1 \#}$, Dibyajit Lahiri ${ }^{1 \#}$, Sudipta Dash ${ }^{1}$, Sayantani Garai1, Dipro Mukherjee ${ }^{1}$, \\ Ritwik Banerjee ${ }^{1}$, Rina Rani Ray ${ }^{2}$ \\ ${ }^{1}$ Department of Biotechnology, University of Engineering and Management, Kolkata. \\ ${ }^{2}$ Department of Biotechnology, Maulana Abul Kalam Azad University of Technology, West Bengal. \\ Corresponding author. E-mail: raypumicro@gmail.com \\ \#Both authors have equal contributions
}

Received: Aug. 10, 2020; Accepted: Jan. 24, 2021; Published: Apr. 14, 2021

Citation: Moupriya Nag, Dibyajit Lahiri, Sudipta Dash, Sayantani Garai, Dipro Mukherjee, Ritwik Banerjee, and Rina Rani Ray,Strategies of Nanomaterial Application for Enhanced Wound Curing: An Overview. Nano Biomed. Eng., 202 I, I3(2): 109- 26.

DOI: 10.5101/nbe.v13i2.p109-126.
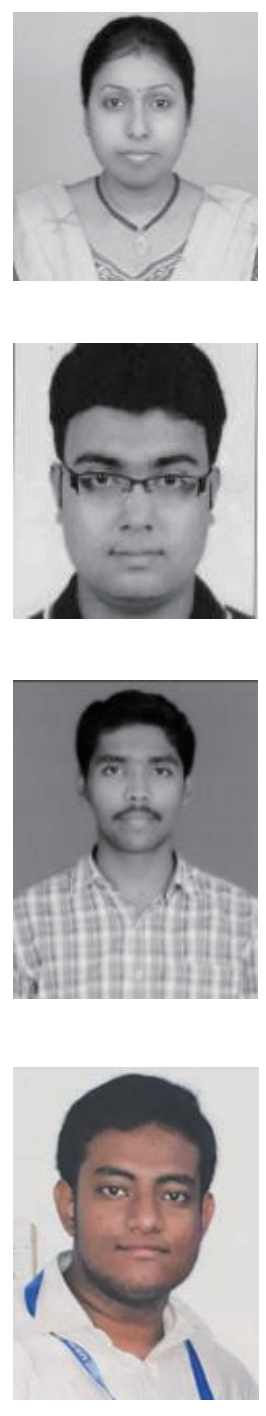

Moupriya Nag is working Assistant professor in the Department of Biotechnology, University of engineering \& Management Kolkata, West Bengal. Her research interests include antimicrobial peptides and drug development. Dr. Nag has published many research papers in various peer reviewed national and international journals.

Dibyajit Lahiri working as Assistant Professor at University of engineering \& Management Kolkata His Research work focus on antibiofilm and antimicrobial studies of various bioactive compounds and their subsequent use as an alternative to antibiotics. He has many publications in international and national journal of repute.

Sudipta Dash has recently graduated from University of Engineering \& Management, Kolkata, with Bachelor of Technology in Biotechnology. His research interest includes (but not limited to) bioinspired nanomaterial synthesis, antimicrobial studies, enzyme purification and cell regeneration-based works. He published his research work in a number of peer reviewed journals.

Dipro Mukherjee is pursuing his B.Tech in Biotechnology. 

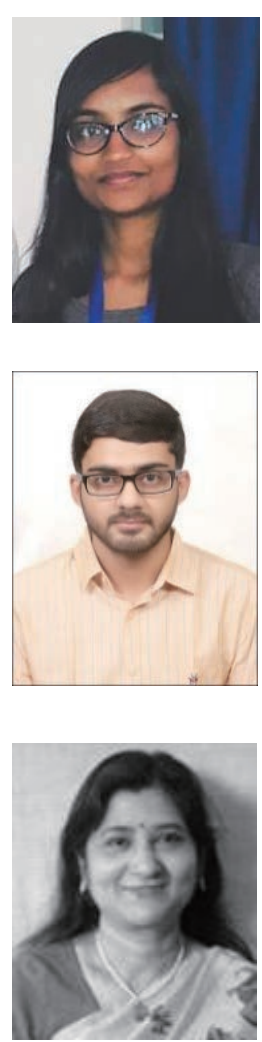

Sayantani Garai is the student of Biotechnology, pursuing her B.Tech in Biotechnology.

Ritwik Banerjee is the student of Biotechnology, pursuing her B.Tech in Biotechnology.

Dr. Rina Rani Ray is presently working as Associate Professor in Department of Biotechnology, Maulana Abul Kalam Azad University of Technology, West Bengal. Her research interest focusses on diverse field of microbial biotechnology. Dr. Ray has published around 80 research papers in various peer reviewed national and international journals and is in the editorial board and a regular reviewer of many journals.

\begin{abstract}
The biological process of healing of wounds deals with the regeneration of cells and is of utmost importance mainly because of the morphological and functional attributes of the tissue. One of the modern approaches is to use novel nanomaterial based wound dressings and other therapeutic treatments that have higher efficiency and specificity. Researchers all around the world have established the competence of various organic, inorganic or polymer-based and biogenically synthesized nanomaterials as a weapon for wound curing. Various matrices carrying nanoparticles like hydrogels, hydrocolloids are used in nano based drug delivery system. The biocompatibility, antimicrobial efficacy and sustained rate of drug delivery are the three main features that are considered for designing a nano drug for effective wound healing. The modification of the nanosized liposome using propylene glycol increases cell-permeation and retention in skin layer. Curcumin loaded liposomes show high anti-inflammatory effect, carbon nanodots (CNDs) and graphene oxide based nanosheets have also shown an immense importance in possessing high surface area. They also show potency in promoting fibroblast growth factors and collagen deposition for speedy recovery of wound. Moreover, the chronic wounds, that could not be cured by common antibiotics, can be addressed by nano based drugs not only for their easy penetration to deeper layer of tissues but also for their efficiency in killing some biofilm associated bacterial strains. Hence, nowadays nano based dressing materials are widely used for rapid recovery of wounds of various types.
\end{abstract}

Keywords: Wound healing, Cell regeneration, Nanoparticles, Green synthesis

\section{Introduction}

Wound healing is one of the many essentially required complex but well-orchestrated natural phenomena that is spatiotemporally regulated to restore the physical integrity of the tissue [1]. The curing of wounds is of substantial importance as exposed region of body provides a profound location for the invasion of disease-causing agents. It has been found by a retrospective analysis and also reported in an article of Wound Healing Society (2019) that around 8.2 million of population has been affected by wounds with or without infection [2, 3]. Statistics inform us that $2 \%$ of the population in developed countries is affected by chronic wounds and more than about 305 million in the world altogether are recorded and treated for acute, traumatic and burn wounds [3, 4].

Wound healing is a controlled mechanism where 
multiple growth factors such as chemokines and cytokines, and signaling molecules like interleukins (ILs) help in coordination for cell to cell and cell to extracellular matrix (ECM) interaction that eventually lead to re-epithelialization [5]. There are various phases of wound healing like hemostasis, inflammation, proliferation and remodeling [6]. The natural flow of these stages can be disturbed or slowed down by the impaired fibroblasts, decreased angiogenesis, impaired adhesion or signaling, enhanced protease level etc. Moreover, there is a considerable amount of chance of these wounds being affected by harmful microbes especially in a place where there is unproper facilities for disinfection, sterilization and cleanliness. The situation is worsened when wound surface is colonized by Multiple Drug Resistant Bacteria (MDRB) [1, 7].

During the last few decades, continuous deployment of antibiotic or antimicrobial drugs has led to dramatic increase in the resistance of bacteria towards the drugs thereby increasing the number of MDRBs. Continuous, inappropriate and sometimes overuse of certain drugs can not only genetically mutate bacteria, but also may draw resistance in other pathogenic organisms such as virus, fungi, parasites etc. [8] There can be broadly two underlying mechanisms of bacteria growing resistant to multiple drugs. Firstly, they can accumulate multiple genes each of which can code the proteins to gain resistance towards single drug. This accumulation is generally associated with R-plasmids. Secondly, heightened expression of efflux pump proteins that may result in increased efflux of multiple drugs from the bacterial cell. Resistance to various drugs such as macrolides, azole derivatives, $\beta$-lactamases, DNA and RNA synthesis inhibitors has already been observed [9].

Another major concern of multiple drug resistance is the formation of biofilms on the wounds. These are assemblage of microbial cells on biotic and abiotic surfaces that can sometimes cause severe health issues. The free-floating planktonic form of bacteria, to facilitate survival during adverse conditions, adheres to a surface leading to formation of biofilms (Table 1). It has been well documented that bacteria residing within biofilms can grow significant resistance against drugs. A study by James et al. has shown that almost $60 \%$ of the observed chronic wounds and $6 \%$ of the observed acute wounds contain biofilms [10]. The virulence factors in bacterial biofilm can disbalance host immune response and the physical barrier created by the extracellular polymeric substance (EPS) can affect inflammatory cell phagocytosis. Further, biofilms may potentially cause inhibition of cascade mechanism of complement proteins and reduce penetrating ability of the drugs. Therefore, an alternative method to target the specific cells to influence wound healing and at the same time inhibit the growth of microorganisms will be of utmost importance.

However, with the recent progress in clinical research, one of the most promising technologies that can revolutionize the medicinal approach of treatments,

Table 1 Types of wounds associated with multidrug resistant organisms [13-16]

\begin{tabular}{|c|c|}
\hline Organism & Infection site / infection type \\
\hline Acinetobacter baumannii & Lung; indwelling devices; bine; blood; implants \\
\hline b-lactamase-producing E. coli & Urinary tract; biliary; gastrointestinal, implants; diabetic wounds \\
\hline b-lactamase-producing Klebsiella pneumonia & Lung; indwelling devices; bine; blood; implants; ulcers \\
\hline Resistant Mycobacterium tuberculosis & Lung \\
\hline Vancomycin-resistant enterococci & $\begin{array}{l}\text { Cardiovascular; intra-abdominal; implants; indwelling devices; joint; } \\
\text { respiratory and bloodstream infection }\end{array}$ \\
\hline MDR S. pneumoniae & Ear; lung; cerebrospinal fluid \\
\hline P. aeruginosa & Urinary tract; indwelling devices; implants; otitis; pyoderma; diabetic wounds \\
\hline Methicillin-resistant Staphylococci & Surgical wounds; skin and soft tissue infection; diabetic wounds \\
\hline Acinetobacter sp & Intravenous catheter; surgical drain infections; incision and wound infections \\
\hline Streptococcus milleri group & Diabetic wounds \\
\hline Clostridium spp. & Diabetic wounds; ulcers \\
\hline Proteus mirabilis & Diabetic foot infections \\
\hline
\end{tabular}


is the application of nanomaterials as therapeutics. It can be seen as a more effective and efficient alternative to the drug delivery systems and wound dressings. It not only has the broad range of application in this context but can also provide us with the flexibility in terms of target-specific therapy. It can be applied in two ways - either its feature can directly affect the wound or it can be used as a carrier to enhance the exposure of the drug to the targeted wound.

Although few reviews are available on application of nano materials for wound healing, most of them have focused on a particular type of nanomaterials or nanobased scaffold for the treatment of wound associated infections [11]. But still there is dearth of knowledge on the mechanism of by which the nano based drugs are acting on these wounds addressing their clinical attributes [12]. The present review describes the types of wounds with an overall mechanism of wound healing and the shortcomings of conventional therapeutic measures of wound curing process. The overview intends to appraise the nano based drug delivery system highlighting their effectiveness and expediency.

\section{Wound and its recovery}

An injury that causes the damage of skin with formation of superficial or deep lesion is regarded as a wound. It may be caused by puncture, burn or any other mechanical or chemical injury. It may be open wound or a closed type (contusion). A wound is always invaded by microbes and depending upon the nature of organism the wound may become a chronic one. "Cutaneous wound healing is an essential physiological process consisting of the collaboration of many cell strains and their products.” [17]

\section{The natural process of wound healing}

The process of natural healing divided into four overlapping stages is complex, but also fragile. There is cascade of reactions that occur simultaneously that finally restores the integration of the tissue [17].

At the very first stage (Fig. 1(a)) of the healing process in an injured tissue, an outflow of blood and lymphatic fluid appears initially followed by activation of intrinsic and extrinsic pathways for coagulation that leads to stopping of blood loss [17]. It is known as hemostasis. A short-spanned vasoconstriction (Fig. 1(b)) occurs due to aggregation of platelets at the endothelial lining. It is a hypothermic preventive strategy that is an energy driven process which utilize ATP. Quickly after it, vasodilation occurs leading to influx of the white blood cell, leukocytes, thrombocytes etc. [19].

The natural tendency of the body is to resist against the foreign substances when it is exposed to the external environment after injury. Hence, it elicits an inflammatory response - the second stage of wound healing. It starts along with the hemostasis phase. Platelets, present at highest number at the site of the wound, start secreting certain proinflammatory factors viz. serotonin, bradykinin, prostaglandins, thromboxane etc. that help in inflammation. Further, histamine is secreted dilating the blood vessels, increasing the permeability, thereby causing the proteins to leak into the extravascular space [20]. Neutrophils, lymphocytes and macrophages migrate to
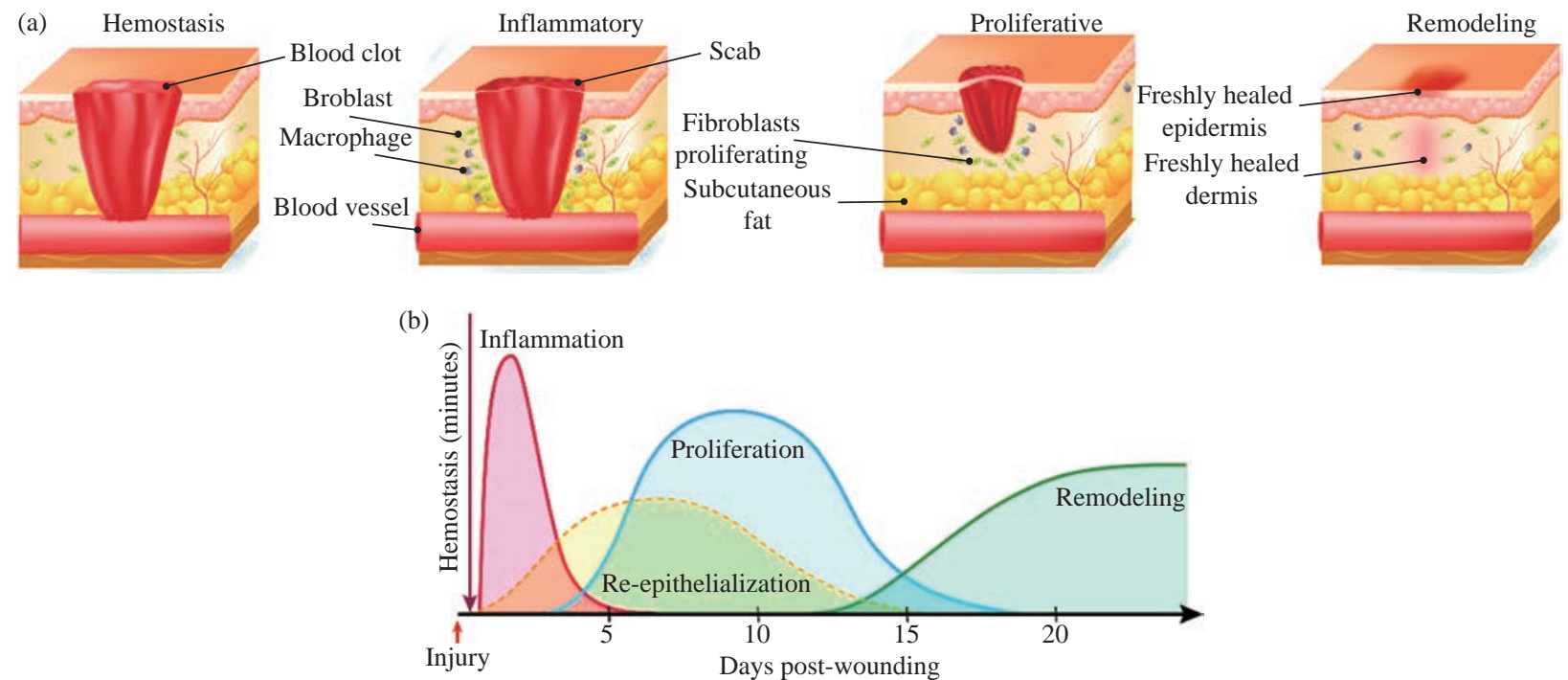

Fig. 1 (a) The major stages of wound healing; (b) Graph showing the overlapping nature of different healing stages [18]. 
the site and help in clearance of the cellular debris and any microbial infection [6].

The proliferative stage where the mechanism of proliferation takes place to fill up the wound-bed. Different growth factors (Table 2) secreted during the inflammatory stage also induce cell proliferation. Moreover, the proliferation is mediated by migration of keratinocytes and fibroblasts [21]. Fibroblasts cells are important for angiogenesis and collagen synthesis. Collagen deposition occurs on the fibrin-fibronectin clots. Fibroblast cells, after proliferation, secrete various ECM proteins such as fibrin, fibronectin, glycosaminoglycans and proteoglycans etc. that support angiogenesis. The entire event leads to the granulation tissue formation that is essential for the healing. In the meantime, being stimulated by the different growth factors earlier released by different cells like macrophages, platelets etc., endothelial cells that help in initiating neovascularization leading to improved nutrient and oxygen exchange through the wound bed [22].

Finally, comes the remodeling stage. Collagen fibers are arranged and cross-linked all over the woundsurface and meanwhile fibroblast cells differentiate into myofibroblasts. These myofibroblasts possess cytoplasmic actin like filaments and therefore, help in contraction of wound [26].

\section{Established Methods Nanomaterials in wound healing}

Nanotechnology is considered to be one of the modern fields of science that spreads across multiple disciplines in terms of application. Particles upto size of $100 \mathrm{~nm}$ is dynamically designed or synthesized showing diverse properties. When a particle is nanoscaled, its surface area increases exponentially decreasing the volume as well as increasing the efficacy in interaction, therefore bringing it a unique physio-chemical property that is extremely useful in medical science [27]. Due to recent advancement in nanoscience, different nano-based systems have already been designed that not only can increase the efficacy due to greater surface area, but also increase specificity by providing targeted delivery of drugs.

\section{Metallic nanoparticles in wound healing}

Out of all the metals, silver (Ag) is probably the most widely studied metal in synthesis of nanoparticles. Silver nanoparticles (Ag NPs) are basically studied because it exhibits significant antibacterial property. So, it is very much efficient against multiple drug resistance bacteria and due to the presence of strong negatively charged surface, they are highly reactive [28]. Along with that, it can reduce the secretion of cytokines and thereby decreasing

Table 2 List of different growth factors associated with wound healing [23-25]

\begin{tabular}{|c|c|c|c|}
\hline Sl. No. & $\begin{array}{l}\text { Growth } \\
\text { factors }\end{array}$ & Source of cells & Mode of action \\
\hline 1. & PDGF & $\begin{array}{l}\text { Platelets; fibroblasts; macrophages; vascular } \\
\text { endothelial cells; vascular smooth muscle cells }\end{array}$ & $\begin{array}{l}\text { 1. Regulates cell growth and proliferation. } \\
\text { 2. Acts as chemoattractant. } \\
\text { 3. Promotes cytokine secretion }\end{array}$ \\
\hline 2. & VEGF & $\begin{array}{l}\text { Platelets; fibroblasts; } \\
\text { macrophages; keratinocytes }\end{array}$ & $\begin{array}{l}\text { 1. Initiates angiogenesis. } \\
\text { 2. Granulation tissue formation. } \\
\text { 3. Proliferation and migration of endothelial cells. }\end{array}$ \\
\hline 3. & EGF & Platelets; fibroblasts macrophages & $\begin{array}{l}\text { 1. Stimulates proliferation and miration of keratinocytes. } \\
\text { 2. Increases tensile strength of skin. } \\
\text { 3. Enhances production of fibronectin. }\end{array}$ \\
\hline 4. & TGF- $\alpha$ & Platelets; macrophages; keratinocytes & $\begin{array}{l}\text { 1. Induces angiogenesis. } \\
\text { 2. Activates EGF receptors. }\end{array}$ \\
\hline 5. & IGF & $\begin{array}{l}\text { Liver cells; fibroblasts; macrophages; } \\
\text { neutrophils; hepatocytes }\end{array}$ & $\begin{array}{l}\text { 1. Inhibits gastric secretion. } \\
\text { 2. Stimulates fibroblast proliferation. }\end{array}$ \\
\hline 6. & bFGF & Fibroblasts; macrophages; endothelial cells & $\begin{array}{l}\text { 1. Stimulate proliferation, migration. } \\
\text { 2. Angiogenesis in injured skin. }\end{array}$ \\
\hline 7. & KGF & Fibroblasts & $\begin{array}{l}\text { 1. Acts as a mitogen for epithelial cells. } \\
\text { 2. Promotes the proliferation, migration and morphogenesis of epithelial cells. }\end{array}$ \\
\hline 8. & TGF- $\beta$ & $\begin{array}{l}\text { Platelets; fibroblasts; } \\
\text { macrophages; keratinocytes }\end{array}$ & $\begin{array}{l}\text { 1. Chemoattractant for macrophages. } \\
\text { 2. Acts as a mitogen for fibroblasts. } \\
\text { 3. Promotes granulation tissue formation. }\end{array}$ \\
\hline
\end{tabular}


the effect of lymphocytes and mast cells (secreting histamine) causing reduction in inflammation [29]. Another advantage of using silver is that it is easier to synthesize in varying range of size (2-100 nm) and shape which gives much flexibility in terms of morphology [30]. Meanwhile, it can also be useful as an ingredient to wound-dressing material. The study by Tian et al. (2007) showed that Ag NP impregnated dressing was successful against normal as well as diabetic mice [31]. However, it has been found that the continued exposure of Ag NPs can be toxic and extremely sensitive to the regenerative cells. In an exvivo study of different silver dressings it was found that the presence of silver delays the re-epithelialization of cells. Hence, the Ag NPs need to be carefully handled when applied directly or indirectly on the wounds [32].

Gold nanoparticles (Au NPs) are also well-studied and advantageous to treat against wounds. These are more chemically stable than the Ag NPs and hence have slightly lower cytotoxicity. However, it shows intrinsic antibacterial and antioxidant property [33]. In a recent research, a combined treatment of Au NP with antioxidant drugs epigallocatechin gallate and $\alpha$-lipoic acid showed accelerated angiogenesis [34]. Au NPs can exhibit bactericidal and bacteriostatic properties as it can either target bacterial cell wall directly or block the unwinding of the super-coiled DNA during replication and transcription. Although, it has been seen that the application of the lower concentration of $\mathrm{Au}$ $\mathrm{NP}$ at the site induces cellular growth and accelerates keratinocyte differentiation, it has also been found that significant higher concentration can also be harmful due to increased cytotoxicity [35].

Zinc oxide nanoparticles ( $\mathrm{ZnO}$ NPs) are probably the most reliable NPs in terms of exhibiting antimicrobial activity due to ROS (Reactive Oxygen Species) activity. It can perturb the bacterial cell membrane [36]. Further, it is biocompatible. In a recent study, based on an in vitro model, when fibroblast cell lines were studied with exposure to $\mathrm{ZnO}$ NPs, growth and enhanced proliferation of the fibroblast cells were observed [37]. To increase the efficacy, it is often associated by chitosan or hydrogel based wound dressing material for better delivery of the drugs. The contraction of wound and re-epithelialization is accelerated by the $\mathrm{ZnO}$ NPs. However, at higher concentration it can also cause dysfunction of mitochondria in keratinocytes and sometimes can inhibit gene expression of superoxide dismutase and glutathione peroxidase ultimately leading to oxidative stress and apoptosis of the cells [27].
Palladium nanoparticle can be useful because of its efficient photothermal property. In a study, size depended Pd nanoparticles produced ( $2 \mathrm{~nm})$, showed significant inhibition of growth against wound causing bacteria like E. coli and $S$. aureus. It was proposed that the activity of the Pd nanoparticles were due to its high reactivity against enzymes such as succinate dehydrogenase, creatine kinase etc. 100\% mortality of S. aureus was resulted within four hours of exposure with these nanoparticles at the concentration of $10^{-9} \mathrm{M}$ only [69]. In another study Pd nanoparticles were used on skin discs in an organ culture experiment. It reduced oxidative and cellular damages and restricted skin thinning. Moreover, oxidative deterioration of the tissue was also controlled. This proves potential application of Pd nanoparticles in skin [38, 39] (Table 3).

Platinum has high catalytic property that makes it beneficial for nano based therapeutic applications. In a recent study by AL Ruiz et al. (2020), novel silver (Ag) - platinum (Pt) assembly was synthesized that showed marked reduction in the colony count of $S$. aureus, $P$. aeruginosa and multi-drug resistant $E$. coli. Furthermore, it has been proven to be effective against cancer cells because of its selective nature [40, 41]. In another study, platinum was added in titanium-silicate nanoparticles to generate punctual defects and thereby enhances the biocatalytic property. Regeneration of tissue was observed in an in-vivo model using diabetic mouse wounds. Along with the healing effect it showed low cytotoxicity and bactericidal effect also making it highly potential for biomedical application [42].

Copper nanoparticles have the ability to affect the expression of hypoxia inducible factor (HIF1a) and vascular endothelial growth factor (VEGF). Further, they can also be used as an antimicrobial and antioxidant agent. In an in-vivo sample of Wister rats, when novel synthesized Cu NPs were applied, cell proliferation and collagen production were observed [43]. Green synthesized copper nanoparticles were produced by Tahvilian et al. (2019) using Allium saralicum to apply on cutaneous wounds. Substantial reduction of wound area and remarkable raise in neutrophil, macrophage and lymphocyte cells was noted. Besides, it exhibited both antibacterial and antifungal activity [44]. Even hydrogel mediated drug delivery system is also quite common with copper nanoparticles. The photothermal activity of the copper can reduce bacterial growth promoting the healing of wounds [45]. 
Table 3 Metallic NPs and its description, utilities and limitations

\begin{tabular}{|c|c|c|c|c|}
\hline Nanoparticles & Application in wound healing & Advantages & Limitations & References \\
\hline $\begin{array}{l}\text { Silver Nanoparticles } \\
\text { (Ag NPs) }\end{array}$ & $\begin{array}{l}\text { It has a profound role in the mechanism } \\
\text { of wound healing by releasing Ag ions } \\
\text { into the bacterial cells thereby damaging } \\
\text { the intracellular nuclear membranes } \\
\text { following by degradation of DNA } \\
\text { and RNA. It also enunciated the the } \\
\text { mechanism of wound healing by the } \\
\text { reepithelization. }\end{array}$ & $\begin{array}{c}\text { Antibacterial property, antiviral, } \\
\text { antifungal, and anti-inflammatory } \\
\text { properties. }\end{array}$ & -- & 131,132 \\
\hline $\begin{array}{l}\text { Gold nanoparticles } \\
\text { (Au NPs) }\end{array}$ & $\begin{array}{l}\text { Help in the killing of microbes that } \\
\text { are associated with the wounds. It also } \\
\text { forms cross links with collagen and can } \\
\text { be easily integrated with biomolecules } \\
\text { like polysaccharides, various types of } \\
\text { growth factors, cell adhesion molecules } \\
\text { and proteins. }\end{array}$ & $\begin{array}{l}\text { It helps in the release of reactive oxygen } \\
\text { species (ROS), helps in the delivery of } \\
\text { genes, and also acts as scavengers. }\end{array}$ & -- & 133, 134 \\
\hline $\begin{array}{l}\text { Copper nanoparticles } \\
\text { (Cu NPs) }\end{array}$ & $\begin{array}{l}\text { It enunciates the process of wound } \\
\text { healing and results in the closing of } \\
\text { wound within a period of } 14 \text { days. }\end{array}$ & $\begin{array}{l}\text { It has antimicrobial properties help in } \\
\text { accelerating the mechanism of wound } \\
\text { healing. }\end{array}$ & $\begin{array}{l}\text { It has shown toxicity within } \\
\text { animal models. Long-term } \\
\text { toxicity within human is still } \\
\text { unknown. }\end{array}$ & 135,136 \\
\hline $\begin{array}{l}\text { Zinc oxide nanoparticles } \\
(\text { ZnO NP) }\end{array}$ & $\begin{array}{l}\text { It results in the process of angiogenesis } \\
\text { and chemotaxi thus resulting in the } \\
\text { process of wound healing. }\end{array}$ & $\begin{array}{l}\text { Antimicrobial in nature, and thus help } \\
\text { in killing microbial cells associated with } \\
\text { the wound. }\end{array}$ & -- & 137 \\
\hline Silica Nanoparticles & $\begin{array}{c}\text { It plays an important role in proliferation } \\
\text { and mitigation of skin fibroblast thus } \\
\text { helping in the mechanism of wound } \\
\text { healing. }\end{array}$ & $\begin{array}{c}\text { Non-toxic; } \\
\text { Biocompatible; } \\
\text { biodegradable } \\
\text { High surface area; } \\
\text { easy mechanism of loading drugs. }\end{array}$ & $\begin{array}{l}\text { Due to porous nature of } \\
\text { the NPs, it may result in } \\
\text { haemolysis. It may also } \\
\text { result in the development of } \\
\text { melanoma. }\end{array}$ & 138, 139 \\
\hline $\begin{array}{l}\text { Cerium dioxide } \\
\text { nanoparticles }\end{array}$ & $\begin{array}{l}\text { It helps in protecting the cells from } \\
\text { oxidative damage by taking up ROS }\end{array}$ & $\begin{array}{l}\text { Antibacterial, antioxidanat and } \\
\text { antifungal properties }\end{array}$ & $\begin{array}{l}\text { Toxicity is found within } \\
\text { animal model. Long-term } \\
\text { toxicity in human is still } \\
\text { unknown. }\end{array}$ & $140-142$ \\
\hline $\begin{array}{l}\text { Titanium dioxide } \\
\text { nanoparticles }\end{array}$ & $\begin{array}{l}\text { Helps in the regeneration of tissues due } \\
\text { to its high tensile strength, corrosion } \\
\text { resistant and promotes cellular } \\
\text { adherence and proliferation. }\end{array}$ & $\begin{array}{l}\text { Antiinflammatory, antibacterial, possess } \\
\text { photocatalytic activities,biocompatible, } \\
\text { and long-term dtability. }\end{array}$ & $\begin{array}{l}\text { Sometimes it results in the } \\
\text { development of inflammatory } \\
\text { responses, ehnaces cellular } \\
\text { uptake and accumulation at } \\
\text { subcellular levels. }\end{array}$ & 143,144 \\
\hline
\end{tabular}

\section{Polymeric nanostructures}

Polymeric nanoparticles are biocompatible nanostructures polymeric substances that can carry the desired drug and protect it from the internal degradation or protease activity. Hence, these polymeric substances can act as excellent delivering material. The polymeric substance must be biodegradable, bioresorbable and metabolized by the host itself [20].

Among the various polymeric nanostructures, hydrogels are probably the most studied one. They can be formed by various synthetic materials such as polylactide, copolymers, polycaprolactones, and polyacrylates even polylactide-polyglycolide and Lactide-glycol-lidecopolymers can be used. Among the natural polymeric substances to produce or carry nanostructures, alginate, albumin, chitosan and polysaccharides are widely explored [46]. Collagen, the most abundantly present protein, can also be used to synthesize polymeric nanoparticles. NPs fabricated collagen is advantageous because it can maintain chemical stability and thermostatic microenvironment that accelerates normal wound healing process. Using covalent cross-linking novel nanocomposites can be synthesized based on collagen, Ag NPs and histidine that exhibit comparatively better mechanical strength as well as antibacterial property [47]. Whereas, nonimmunogenic and highly compatible gelatin-based hydrogels when loaded with nanoparticles can show adequate swelling property and antimicrobial property when applied on a moist wound [48]. Extracted from the exoskeleton of crustacean arthropods, hydrophilic chitosan is also an effective biopolymer that is mainly studied for its high bioavailability, antibacterial activity and very low toxicity [27] (Table 4).

\section{Scaffolds}

Nano-scaffold, generally produced by electrospinning, is a well-known term in tissue engineering. It is a nano-scaled fibrous material made of polymeric substances that mimics the natural architecture of the native ECM present at the site of wound. Therefore, it can serve as a carrier of cells at the site of wound and also can be suitable for controlled drug release 
Table 4 Polymeric nanomaterials and its description, utilities and limitations

\begin{tabular}{|c|c|c|c|c|c|}
\hline Sl no. & $\begin{array}{c}\text { Polymeric } \\
\text { nanoparticle }\end{array}$ & Description & Utility & Limitations & References \\
\hline 1. & Hydrogels & $\begin{array}{l}\text { 1. Synthesized by crosslinked hydrophilic } \\
\text { polymers, e.g. polyvinyl } \\
\text { alcohol, polyvinyl pyrrolidone, or } \\
\text { polyethylene oxide. } \\
\text { 2. Water and glycerin-based dressing available } \\
\text { in sheet, gel or impregnated gauzes. }\end{array}$ & $\begin{array}{l}\text { 1. Used in ulcers, laser resurfacing, } \\
\text { graft donor sites and artificial } \\
\text { organ donor site. } \\
\text { 2. Efficient for wounds with minimal } \\
\text { or no exudates. } \\
\text { 3. Useful for maintaining moist } \\
\text { environment. }\end{array}$ & $\begin{array}{l}\text { 1. Wounds with excessive exudates } \\
\text { may require secondary dressing. } \\
\text { 2. Not absorptive enough for } \\
\text { moderate to highly exudative } \\
\text { wounds. }\end{array}$ & $49-51$ \\
\hline 2. & Hydrocolloids & $\begin{array}{l}\text { 1. Occlusive and adhesive wafer dressings } \\
\text { which combine absorbent colloidal materials } \\
\text { with adhesive elastomers. } \\
\text { 2. Contain absorptive particles that interact } \\
\text { with moisture to form a gelatinous mass. }\end{array}$ & $\begin{array}{l}\text { 1. React with wound exudates and } \\
\text { form gel-like covering and hence } \\
\text { protects the wound. } \\
\text { 2. Provide a moist wound } \\
\text { environment and promote } \\
\text { autolysis. }\end{array}$ & $\begin{array}{l}\text { 1. May not be able to manage } \\
\text { copiously draining wounds. } \\
\text { 2. Degradation of the dressing } \\
\text { materials may produce a residue } \\
\text { of varying colors and possible } \\
\text { foul odor. }\end{array}$ & $49-51$ \\
\hline 3. & Chitosan & $\begin{array}{l}\text { 1. Abundantly available linear polysaccharide } \\
\text { and highly biocompatible. }\end{array}$ & $\begin{array}{l}\text { 2. Hemostasis and tissue adhesive } \\
\text { property. } \\
\text { 3. Excellent antimicrobial activity } \\
\text { and good carrier od drugs. }\end{array}$ & $\begin{array}{l}\text { 1. Low solubility in neutral and } \\
\text { acidic } \mathrm{pH} \text {. }\end{array}$ & 50,52 \\
\hline 4. & Alginate & $\begin{array}{l}\text { 1. Fibrous sheet derived from brown seaweed. } \\
\text { 2. Main component is alginic acid. }\end{array}$ & $\begin{array}{l}\text { 1. Provide a moist wound } \\
\text { environment and facilitate } \\
\text { autolysis. } \\
\text { 2. Non-adherent, and high } \\
\text { mechanical stability. }\end{array}$ & $\begin{array}{l}\text { 1. Costly. } \\
\text { 2. Difficult to handle. }\end{array}$ & 50,51 \\
\hline 5. & Keratin & $\begin{array}{l}\text { 1. Naturally occurring insoluble protein. } \\
\text { 2. Fibrous protein found in filamentous hair, } \\
\text { nails etc. }\end{array}$ & $\begin{array}{l}\text { 1. Acts as a nanoparticle carrier. } \\
\text { 2. Good adhesive property and aids } \\
\text { cell proliferation. } \\
\text { 3. Supports fibroblast formation. }\end{array}$ & $\begin{array}{l}\text { 1. Water insoluble. } \\
\text { 2. Poor stability. }\end{array}$ & 53,54 \\
\hline 6. & Collagen & $\begin{array}{l}\text { 1. Derived from bovine material. } \\
\text { 2. Processed and shaped into sheets, particles, } \\
\text { or gels. }\end{array}$ & $\begin{array}{l}\text { 1. Promotes granulation and } \\
\text { epithelialization. } \\
\text { 2. Suitable for chronic wounds. } \\
\text { 3. Maintains chemical and } \\
\text { thermostatic micro-environment. }\end{array}$ & -- & 50,54 \\
\hline 7. & Silk fibroin & $\begin{array}{l}\text { 1. Primary constituents of silk-protein derived } \\
\text { from Bombyx mori. }\end{array}$ & $\begin{array}{l}\text { 1. Morphological flexibility and } \\
\text { mechanical stability. } \\
\text { 2. Highly biocompatible and good } \\
\text { carrier for nanoparticles. } \\
\text { 3. Promotes epidermal growth. }\end{array}$ & $\begin{array}{l}\text { 1. Opaque cross-linking system. } \\
\text { 2. Low elasticity. }\end{array}$ & 54,55 \\
\hline 8. & $\begin{array}{l}\text { Transparent } \\
\text { polymeric film }\end{array}$ & $\begin{array}{l}\text { 1. Synthesized from polyurethane or any other } \\
\text { polymeric materials. } \\
\text { 2. Has flexible, transparent and self-adhesion } \\
\text { property. }\end{array}$ & $\begin{array}{l}\text { 1. Permeable to gas. } \\
\text { 2. Impermeable to bacteria and fluid. } \\
\text { 3. Easy monitoring of wound. } \\
\text { 4. Economical. }\end{array}$ & $\begin{array}{l}\text { 1. Risk of affecting wound bed } \\
\text { while removing due to high } \\
\text { adhesive property. } \\
\text { 2. Non-absorbent }\end{array}$ & $49-51$ \\
\hline
\end{tabular}

[56]. The scaffolds adhesive in nature - they help in attachment of the cells to the cell surface receptors and create convenient microenvironment for proliferation. In a study, where $\mathrm{TiO}_{2}$ nanomaterial carrying nanoscaffold was applied to the wound, better skin repair was observed. The physiochemical studies showed better permeability and stability of the of the dressing. Even the embedded nano- $\mathrm{TiO}_{2}$ helped in successful inhibition of the growth of Staphylococcus aureus [57]. Electrospinning is generally used for production of nano-scaled scaffolds because of its ability to process large scale and easy control of the fiber diameter. In a research, nano-scaffolds have been found to attenuate the collagen synthesis property [58]. A novel treatment deals with incorporation of stem cells, growth factors and matrix elements into nanoscaffold and applying it on the wound-bed. Direct delivery of mesenchymal stem cells (MSCs) rapid cell death and reduction in proliferation. However, nano- scaffold based treatment seems to be comparatively effective in comparison to classical nanoparticles. The nano-topography of the surface of the scaffolds is such that a chemical conjugation between the surface CD29 antibody and CD29 antigen overexpressed in MSCs will occur, which will contribute to increase the cell adhesion property of the stem cells. In another research, a nanocomposite of bone marrow stem cells and nano-scaffold was designed and showed successful regeneration of skin when tested on acute skin wounds. Though the therapy is still in its learning stage and has not yet been approved by the FDA, but the advancement and future with nano scaffolds seem promising [59].

\section{Liposome}

Liposomes resemble the lipid cell membrane. They are colloidal bilayer vesicles made up of amphiphilic molecules like phospholipids. Due to their excellent 
ability of acting as a carrier, biocompatibility and size, surface and charge modulation property, they are good substances of drug delivery. It has been observed that the damage of co-receptors for growth factors in case of diabetes causing the prevention of angiogenesis and cell proliferation [60]. However, this can be overcome by delivering proteo-liposomes loaded with coreceptors and growth factors to the site. When tested on diabetic mouse, the treatment showed positive result with enhanced vascularization [22]. A special type of liposome consisting of phospholipids and an edge activator shows topical activity. The edge activator provides the liposome high flexibility and enables it to reach viable epidermis by crossing stratum corneum [20]. Even, modification of nanosized liposome using propylene glycol increases cell-permeation and retention in skin layer. Curcumin loaded liposomes show high anti-inflammatory effect. It also induces longer exposure of the carried compound at the site of the wound [61]. In another type of liposome mediated treatment, solid lipid nanoparticles are used. These solid lipid nanoparticles (SLNs) have their solid lipid core stabilized by surfactants, therefore, they could solubilize lipophilic molecules [27] (Table 5).

\section{Non-metallic nanoparticles}

Among the non-metallic nanoparticles, carbon nanodots (CNDs) are most popular. In a study where onion derived carbon nanodots (OCND) were synthesized and applied on the human foreskin fibroblast (HFF) cells, enhanced proliferation was observed. Further, the test showed excellent cytocompatibility and also gave positive result in hemolysis assay [73]. Introduction of carbon nanodots along with polymeric matrix like polymethacrylate, polyurethane etc., showed both enhanced self-healing and anticorrosion activity [74]. There is graphene oxide based nanosheets that have high surface area and optical, electronic and quantum properties. In a recent research, amorphous silica-based nanoparticle was used to deliver silicic acid to the site - rapid wound closure and proliferative activity of the fibroblast cells were observed. Moreover, it was found to be non-toxic and effective against the wound [75].

\section{Green synthesized nanoparticles}

Chemical synthesis of nanoparticles can be beneficial in many ways as already mentioned. However, the problem being the use of hazardous chemicals during the chemical synthesis is also a concern as they have severe harmful effects on the environment, especially if the process is to be industrialized. Moreover, the process of synthesis is quite expensive and there are higher chances of side

Table 5 Liposome based drug delivery in wound healing

\begin{tabular}{|c|c|c|c|c|c|}
\hline Sl no. & Drug & Administration & Outcome & Limitations & Ref. \\
\hline 1 & bFGF & Smear wound & $\begin{array}{l}\text { Enhanced regeneration of vascular } \\
\text { vessels, skin appendage repairment } \\
\text { and accelerated wound closure }\end{array}$ & $\begin{array}{l}\text { Maintaining stability of the } \\
\text { liposome in massive wound } \\
\text { fluid is a challenge. }\end{array}$ & 62 \\
\hline 2 & Madecassoside & Applied on burn wounds & $\begin{array}{l}\text { Improved delivery of drug and } \\
\text { accelerated dermal wound repair }\end{array}$ & $\begin{array}{l}\text { Leakage rate increases slowly } \\
\text { with respect to time and } \\
\text { temperature }\end{array}$ & 63 \\
\hline 3 & Repithel & $\begin{array}{l}\text { Topical treatment to } \\
\text { burn wounds }\end{array}$ & $\begin{array}{l}\text { Rapid epithelialization, } \\
\text { faster wound closure }\end{array}$ & $\begin{array}{l}\text { Adverse side effects (like } \\
\text { itching and excessive pain) }\end{array}$ & 64 \\
\hline 4 & Hypericum perforatum oil & $\begin{array}{l}\text { Topical treatment to } \\
\text { burn wounds }\end{array}$ & $\begin{array}{l}\text { Increased fibroblast proliferation } \\
\text { and angiogenesis }\end{array}$ & Less organized granulation & 65 \\
\hline 5 & Curcumin oil & $\begin{array}{l}\text { Topical treatment to } \\
\text { burn wounds }\end{array}$ & Dense fibrosis & Not in the paper & 65 \\
\hline 6 & $\begin{array}{l}\text { Povidone-iodine (PVP-I) } \\
\text { liposome }\end{array}$ & $\begin{array}{l}\text { Topically on patients } \\
\text { with mesh graft }\end{array}$ & $\begin{array}{l}\text { Neo epithelialization and } \\
\text { microbicidal effects }\end{array}$ & Systemic absorption & 66 \\
\hline 7 & Buflomedil hydrochloride & $\begin{array}{l}\text { Topically applied on } \\
\text { hairless mouse }\end{array}$ & $\begin{array}{l}\text { Neo vascularization, } \\
\text { increased proliferation }\end{array}$ & Low solubility & 67 \\
\hline 8 & Danggui Buxue extract & Topical administration & $\begin{array}{l}\text { Affects VEGF and TGF- } \beta \\
\text { mediated pathways }\end{array}$ & $\begin{array}{l}\text { Effects on human has not } \\
\text { been investigated }\end{array}$ & 68 \\
\hline 9 & $\begin{array}{l}\text { Substance P loaded } \\
\text { chitosan }\end{array}$ & $\begin{array}{l}\text { In-vitro study on } \\
\text { HaCaT cell line }\end{array}$ & $\begin{array}{l}\text { Increased rate of cell proliferation } \\
\text { and drug stability }\end{array}$ & $\begin{array}{l}\text { Not well studied in } \\
\text { in-vivo model }\end{array}$ & 69 \\
\hline 10 & $\begin{array}{l}\text { Bacteriophage entrapped } \\
\text { liposome }\end{array}$ & $\begin{array}{l}\text { orally / topically on } \\
\text { diabetic wound }\end{array}$ & $\begin{array}{l}\text { Faster epidermal healing and lysis of } \\
\text { S. aureus bacterial cells }\end{array}$ & Leakage of sample & 70 \\
\hline 11 & Simvastatin & $\begin{array}{l}\text { Topical application on } \\
\text { excision wound }\end{array}$ & $\begin{array}{l}\text { Better entrapment of drug } \\
\text { and efficient delivery }\end{array}$ & Stability decreases at $40^{\circ} \mathrm{C}$ & 71 \\
\hline 12 & Usnic acid & $\begin{array}{l}\text { Topical wound dressing } \\
\text { on burn wounds }\end{array}$ & $\begin{array}{l}\text { Better collagen deposition, } \\
\text { increased rate of granulation }\end{array}$ & Slow rate of releasing & 72 \\
\hline
\end{tabular}


effects. Hence, one of the most preferred method is green synthesis or biological synthesis of nanoparticles because they are environment-friendly, highly biocompatible, cost effective and mostly nontoxic [22]. In general, there are two ways of biological synthesis - first one is the microbial synthesis and the second one is the plant-based synthesis. The bacterial or fungal extracts contain protein and metabolites that can reduce the nanoparticles and stabilize it, thereby producing a green nanoparticle [53]. Tiwari et al. (2014) successfully biosynthesized bacterial cobalt nanoparticles (BCNPs) using cell free extract of Pseudomonas aeruginosa. Using the excision wound model, they showed that the percentage wound healing was twice with BCNPs in just 2 days when compared to the control. Not only it enhanced the closure of the wound site but also it had significant antimicrobial activity [76].

In case of plant extract mediated biosynthesis, the phytocompounds or bioactive compounds i.e. the secondary metabolites of the plants can act both as reducing and stabilizing agent for the core metal atoms. There are various bioactive compounds like alkaloids, flavonoids, saponin, terpenes, limonene, polyphenols etc. found in different plants. These compounds have wide variety of biological application - one of them being the wound healing and angiogenesis property [77]. These plant-derived nanoparticles are extremely cost-effective and even do not require controlled condition as compared to that of the microbial synthesis of nanoparticles. In a recent study, rosamarinic acid loaded chitosan nanoparticles were applied on the rats, sustained release of the drug was ensured that enhanced the rate of wound healing. Even, during irritation tests, it showed no sign of allergic symptoms like erythema or edema on rat skin which proved its biocompatibility [78]. In another study, Syzygium cumini leaf extract was used as a stabilizing agent for Ag NPs and the in vivo application on streptozotocin induced diabetic rats showed enhanced epithelialization and increased wound contraction. Further the hematological parameters such as hct, PLT, RBC, WBC count etc. did not have much variation during Ag NP application [79]. Plant based nanoparticles can also control the inflammatory response by downregulating TNF- $\alpha$, IL-6, IL-1 $\beta$, and IL-10 synthesis by the cells and sometimes can control inflammatory pathways by inhibiting NF-kB [53]. Dhapte et al. (2014) produced biogenic silver nanoparticles using Bryonia laciniosa in a single step method and achieved both antibacterial activity and wound healing property in an in-vivo model. It not only had high stability, but also showed effective cytokine modulation along with improved wound contracting ability [80]. Ahn et al. (2019) synthesized silver nanoparticles using Lindera strychnifolia that when was applied on the mouse fibroblast cells exhibited enhanced proliferation [81]. In another paper, Ahmeda et al (2020) produced titanium oxide nanoparticles using Falcaria vulgaris leaves. Along with cutaneous wound healing, it was effective as both antibacterial and antifungal agent having bactericidal values in the range of $2-8 \mathrm{mg} / \mathrm{mL}$ and $2-16 \mathrm{mg} / \mathrm{mL}$. It had excellent viability on human umbilical vein cells and hence proved to be extremely potential [82]. Recently, Shanmugasundaram et al. (2017) gold - silver monometallic and bimetallic nanoparticles were synthesized using Streptomyces sp., an extremophilic actinobacterium. The biosynthesized nanoparticles exhibited antimicrobial property against gram positive and gram-negative bacteria, also against fungal organisms such as Candida albicans and Candida glabrata. It showed cytokine induction as well as enhancement of hydroxyproline, hexosamine and hyaluronic acid at the site of the wound [83].

\section{Application of Nano Based Technology in Dressing Materials for Wound Care}

The recent developments in the field of nanotechnology and the use of nanocomposites are widely used for the medical purposes. The silver nanoparticles (Ag NP) associated bacterial cellulose (BC) play a vital role as wound dressing material possessing antimicrobial efficacies. The morphology of $\mathrm{BC}$ possessing distinct nanofibrous structure help them in increasing the surface area for holding large amount of water and also possess high wet strength with high elasticity and conformability [84]. The formation of silver nanoparticles was confirmed by the studying the absorption spectrum. It was also observed that the formation of Ag NP resulted in the red shift effect when studied the surface Plasmon resonance (SPR) [85]. Moreover, the Ag NP-BC composite was further confirmed with the use of SEM-EDS spectra. It was also observed that Ag NP-BC nanocomposite show lower amount of stress, strain, load and elongation in comparison to BC which actually possess crystalline structure [86]. The Ag NP-BC composite played an important role in wound dressing as it slowly released 
the antimicrobial agent at the site of wound [87].

The mechanism of repairing the wounds involves various biological processes that involves biochemical cascades and the process of cell signaling. The use of nanomedicines particularly the use of NPs provided a newer strategy to bring about improvement in the tissue regeneration therapies. The NPs might be comprised either of the non-polymeric and polymeric materials which has a higher applicability for medical uses. At recent times the NPs are available in the form of gels or ointments because of the persistent antibacterial activities, low systemic toxicity, low cost and biocompatibility [88]. Ag NPs possess the efficacy in acting against the drug resistant components [89]. The mechanism of utilizing the NP in the process of drug delivery enhances the antibacterial properties and contributes wholesomely in combating against the resistant group of the bacterial cells by the use of the lower concentration of the antimicrobials [89]. It not only possesses the anti-inflammatory property but also help in regulating the deposition of collage resulting in proper orientation of the fibers causing quicker healing up of the wounds [90]. Studies has shown that the use of Ag NPs help in better healing of surface wounds in comparison to the other materials being available in the market. The metallic and polymeric nanoparticles show an effective role not only in eliminating the infection associated microbial cells as well as help in the mechanism of wound healing (Table 6 and 7).

Recent studies have also shown that the chitosan

Table 6 Nanoparticle associated scaffold and its associated activity

\begin{tabular}{|c|c|c|c|c|c|c|c|c|}
\hline \multirow[b]{2}{*}{ NP } & \multirow[b]{2}{*}{ Matrix } & \multirow[b]{2}{*}{ Drug association } & \multicolumn{4}{|c|}{ Properties } & \multirow{2}{*}{$\begin{array}{l}\text { Significance of } \\
\text { Nanomaterial }\end{array}$} & \multirow[b]{2}{*}{ Ref. } \\
\hline & & & Size (nm) & $\begin{array}{l}\text { Encapsulation } \\
\text { efficiency }\end{array}$ & $\begin{array}{c}\text { Zeta } \\
\text { potential }(\mathrm{mV})\end{array}$ & $\begin{array}{c}\text { Poly- } \\
\text { dispersity } \\
\text { index } \\
\end{array}$ & & \\
\hline PLA NPs & -- & Octenidine & 230 & -- & 12 & & $\begin{array}{c}\text { Enzymatic degradation } \\
\text { of the PLLA; high tissue } \\
\text { compatibility (do not induce } \\
\text { a significant inflammatory } \\
\text { response). }\end{array}$ & 91 \\
\hline \multirow[t]{6}{*}{$\begin{array}{l}\text { PLA-10R5- } \\
\text { PLA }\end{array}$} & \multirow[t]{5}{*}{$\begin{array}{l}\text { PLA-10R5- } \\
\text { PLA hydrogel }\end{array}$} & EGF and curcumin & 130 & $\begin{array}{l}\text { EE of curcumin } \\
92 \% \text { and EE of } \\
\text { EGF } 85 \%\end{array}$ & -- & 0.1 & $\begin{array}{l}\text { Injectable solution at room } \\
\text { temperature; after application } \\
\text { to the wound, it became a non- } \\
\text { flowing gel; slow cumulative } \\
\text { release compared with free } \\
\text { drugs. }\end{array}$ & -92 \\
\hline & & LL37 & 305 & $70 \%$ & 21 & 0.18 & $\begin{array}{l}\text { Sustained release of LL37 and } \\
\text { intrinsic lactate, high loading } \\
\text { efficiency. }\end{array}$ & 93 \\
\hline & & VEGF & 203 & $76 \%$ & 30 & 0.07 & $\begin{array}{l}\text { Initial burst of VEGF released } \\
\text { followed by sustained release. }\end{array}$ & 94 \\
\hline & & Curcumin & 177 & $89 \%$ & 23 & 0.105 & $\begin{array}{l}\text { Burst release followed by } \\
\text { gradual and sustained drug } \\
\text { release over a period of } 8 \text { days. }\end{array}$ & 95 \\
\hline & & $\begin{array}{l}\text { NO release by } \\
\text { polyethylenimine/ } \\
\text { diazeniumdiolate }\end{array}$ & 179 & -- & 35 & -- & $\begin{array}{c}\text { Sustained release over } 6 \\
\text { days without burst release. }\end{array}$ & 96 \\
\hline & $\begin{array}{l}\text { Chitosan } \\
\text { nanofibers }\end{array}$ & $\begin{array}{l}\text { PDGF-BB in NPs and } \\
\text { VEGF in nanofibers }\end{array}$ & 150 & -- & -- & -- & $\begin{array}{l}\text { Biphasic release of } \\
2 \text { growth factors. }\end{array}$ & 97 \\
\hline $\begin{array}{l}\text { PLGA } \\
\text { heparin }\end{array}$ & Fibrin gel & Platelet-rich plasma & $180-250$ & -- & -- & -- & $\begin{array}{l}\text { Provided a prolonged release } \\
\text { period; GFs maintained their } \\
\text { bioactivity compared with } \\
\text { fibrin gel PRP in vitro, may } \\
\text { mimic ECM function in vivo } \\
\text { and in vitro. }\end{array}$ & 98 \\
\hline Chitosan & & Hydrocortisone & $187-382$ & $42 \%-86 \%$ & $45-14$ & -- & $\begin{array}{l}\text { Stability and high loading } \\
\text { efficiency of chitosan NPs. }\end{array}$ & 99 \\
\hline & & Melatonin & 250 & $4 \%$ & 25 & 0.35 & $\begin{array}{l}\text { Decreased chitosan } \\
\text { cytotoxicity when } \\
\text { incorporated in NPs. }\end{array}$ & 100 \\
\hline $\begin{array}{l}\text { Chitosan/ } \\
\text { lecithin }\end{array}$ & $\begin{array}{l}\text { Chitosan } \\
\text { hydrogel } \\
\text { with loaded } \\
\text { b-lapachone }\end{array}$ & $\begin{array}{c}\text { b-Lapachone/ } \\
\text { onolaurin b-Lapachone/ } \\
\text { didecyldimethylammonium } \\
\text { bromide }\end{array}$ & 437 / 330 & $26 \% / 52 \%$ & $32 / 90$ & $0.27 / 0.24$ & $\begin{array}{l}\text { Close contact between the } \\
\text { NP and the skin due to } \\
\text { mucoadhesive properties of } \\
\text { the chitosan and produced an } \\
\text { occlusive barrier. }\end{array}$ & 101 \\
\hline $\begin{array}{l}\text { Chitosan/ } \\
\text { polyglutamic } \\
\text { acid }\end{array}$ & $\begin{array}{l}\text { Chitosan } \\
\text { membranes }\end{array}$ & Curcumin & $193-799$ & $53 \%-41 \%$ & $21-19$ & 0.29 to 0.79 & $\begin{array}{l}\text { Composite material using } \\
\text { both the bioactivity of natural } \\
\text { polymers and the stability of } \\
\text { synthetic ones. }\end{array}$ & 102 \\
\hline $\begin{array}{l}\text { Chitosan/ } \\
\text { gelatin }\end{array}$ & $\begin{array}{l}\text { Poly-glutamic } \\
\text { acid)/gelatin } \\
\text { hydrogel + } \\
\text { carbon fibers }\end{array}$ & $\begin{array}{l}\text { NPs: epigallocatechin } \\
\text { gallate; carbon fibers: } \\
\text { gentamicin }\end{array}$ & 230 & $46 \%$ & 29 & 0.06 & $\begin{array}{l}\text { Multicomposite with several } \\
\text { biological targets. }\end{array}$ & 103 \\
\hline
\end{tabular}


Table 7 Multidimensional treatment of wound infections

\begin{tabular}{|c|c|c|c|c|c|}
\hline \multirow{2}{*}{ Types } & \multirow{2}{*}{ Materials } & \multicolumn{3}{|c|}{ Properties } & \multirow{2}{*}{ Ref. } \\
\hline & & $\begin{array}{c}\text { Prevention of } \\
\text { abnormal scarring }\end{array}$ & $\begin{array}{l}\text { Stimulation of } \\
\text { wound healing }\end{array}$ & Anti-bacterial & \\
\hline \multirow{4}{*}{ Nanoparticles } & Silver & $\begin{array}{c}\text { Possess anti- } \\
\text { bacterial properties }\end{array}$ & $\begin{array}{c}\text { Possess anti- } \\
\text { bacterial properties. }\end{array}$ & $\begin{array}{c}\text { Possess anti- } \\
\text { bacterial properties. }\end{array}$ & 104,105 \\
\hline & Gold & $\begin{array}{l}\text { Presence of these properties } \\
\text { are yet not known. }\end{array}$ & $\begin{array}{l}\text { Possess anti- } \\
\text { bacterial properties. }\end{array}$ & $\begin{array}{l}\text { Possess anti- } \\
\text { bacterial properties. }\end{array}$ & 106 \\
\hline & Zinc oxide & $\begin{array}{l}\text { Presence of these properties } \\
\text { are yet not known. }\end{array}$ & $\begin{array}{l}\text { Possess anti- } \\
\text { bacterial properties. }\end{array}$ & $\begin{array}{l}\text { Possess anti- } \\
\text { bacterial properties. }\end{array}$ & 107 \\
\hline & $\begin{array}{l}\text { Composite nanoparticles, e.g. chitosan } \\
\text { nanoparticles, nanocellulose. }\end{array}$ & $\begin{array}{l}\text { Possess anti- } \\
\text { bacterial properties. }\end{array}$ & $\begin{array}{l}\text { Possess anti- } \\
\text { bacterial properties. }\end{array}$ & $\begin{array}{l}\text { Possess anti- } \\
\text { bacterial properties. }\end{array}$ & 108 \\
\hline Nanocarriers & $\begin{array}{l}\text { e.g. Nitric oxide-releasing poly(lactic-co- } \\
\text { glycolic acid)-polyethyleneimine nanoparticles, } \\
\text { curcumin loaded super-paramagnetic iron oxide. }\end{array}$ & $\begin{array}{l}\text { Presence of these } \\
\text { properties are yet not known. }\end{array}$ & $\begin{array}{l}\text { Possess anti- } \\
\text { bacterial properties. }\end{array}$ & $\begin{array}{l}\text { Possess anti- } \\
\text { bacterial properties. }\end{array}$ & 109, 110 \\
\hline $\begin{array}{l}\text { Coatings and } \\
\text { Scaffolds }\end{array}$ & $\begin{array}{l}\text { e.g. Hydrogel preloaded with bFGF; hydrogels } \\
\text { reinforced with Ag NPs. }\end{array}$ & $\begin{array}{l}\text { Presence of these properties } \\
\text { are yet not known. }\end{array}$ & $\begin{array}{l}\text { Possess high percentage } \\
\text { of anti-bacterial } \\
\text { properties. }\end{array}$ & $\begin{array}{l}\text { Possess high } \\
\text { percentage of anti- } \\
\text { bacterial properties. }\end{array}$ & 111 \\
\hline
\end{tabular}

based nanocomposite scaffolds played a wider role in medicinal uses, for the delivery of drugs, wound healing and for the purpose of tissue engineering. The nonmetallic component being incorporated within the chitosan scaffold has showed immense importance because of its effective antimicrobial property [112]. Combination of various metallic elements with the chitosan scaffold showed enormous role in the healing of infection and showing a profound antimicrobial activity. It has also been observed that metallic ions play a vital role in the re-epithelialization of the wound and the chitosan-based nanoparticles regulate their mode of action. It has been observed that incorporation of metallic nanoparticles within the chitosan-based scaffold shows a sustained antimicrobial activity by the mechanism of degrading matrix without bringing about any effect on the viability of the normal cells. The mode of action of the metallic nanoparticles is dependent upon the concentration and the formation of the free radical. Till date very few researches has been reported but the efficiency of the nanocomposite as antimicrobials can be determined using in vitro and in vivo infectious models. Studies also showed that the combinatorial effect of the nanoparticles and the chitosan scaffold enhances the antimicrobial activity. The enhancement in the loading capacity and the release of the nanoparticles can be performed by orienting the fabrication technique. For instance, the purpose of healing of the moist wounds require the scaffold being obtained by the lyophilization technique which would help in absorbing the moisture from the wound and allow the release of metallic ions helping in the speedy recovery of the surface wound infections.

Another concern for medical practitioners and scientists is the post-operative surgical site infections which may lead to various types of complications. The study performed by Arshad et al. (2019) showed that chitosan-alginate embedded zinc-oxide nanoparticles (ZnO-NPs) played a vital role in treating the SSI and showed marked recovery of the infections [113] (Table 8).

Another concern for the medical practitioner is burn wound infections that is one of the important causes of morbidity and mortality throughout the world. Curing the burn wound associated infections and healing of the wound is a major concern for the people around the world. According to the work of Seisenbaeva et al. 2017 was observed that $\mathrm{TiO}_{2}$ nanoparticles possess the ability of absorbing the proteins and thus resulted in the coagulation of the fluid and thus created a protective coating of hybrid materials. It was further observed that the interaction between the human blood and tinatia resulted in the increased concentration of $\mathrm{TiO}_{2}$ which helped in the formation of a dense gel composite materials which played a vital role in the regrowth of the skin [129] (Table 9).

\section{Conclusions}

Today, nanoparticle-based therapies are reducing the barriers of wound healing going beyond the traditional approach and bringing increased target specificity. They have high therapeutic potential both in terms of biological as well as synthetic molecules. Various novel wound dressing materials are being designed that can help the patients recover early [130]. Another advantage associated with this approach is the biodegradability and biocompatibility with the in vivo systems especially in case of application of 
Table 8 Metallic nanoparticles and their activities

\begin{tabular}{|c|c|c|c|c|c|}
\hline $\begin{array}{c}\text { Metallic } \\
\text { Nano-particle }\end{array}$ & Matrix & Properties & Tested micro-organisms & In vivo & Ref. \\
\hline \multirow{6}{*}{ Ag NP } & $\begin{array}{l}\text { Chitosan/sago starch } \\
\text { (nanocomposite film) }\end{array}$ & $\begin{array}{l}\text { Improved mechanical properties; } \\
\text { antimicrobial; higher granulation } \\
\text { tissue and tensile strength. }\end{array}$ & -- & $\begin{array}{l}\text { Open excision } \\
\text { wound (male } \\
\text { Wistar rats) }\end{array}$ & 114 \\
\hline & Chitosan gel & Bactericidal & $\begin{array}{c}\text { Biofilm of } \\
\text { MRSA \& } \\
\text { P. aeruginosa }\end{array}$ & -- & 115 \\
\hline & $\begin{array}{l}\text { 4-(ethoxycarbonyl) phenyl-1- } \\
\text { amino oxobutanoic acid- } \\
\text { chitosan (nanocomposite film) }\end{array}$ & Antimicrobial & $\begin{array}{l}\text { P. aeruginosa, } \\
\text { S. aureus and E. coli }\end{array}$ & -- & 116 \\
\hline & $\begin{array}{l}\text { Chitosan blended with } \\
\text { poly(vinyl alcohol) } \\
\text { (fibrous sheet) }\end{array}$ & $\begin{array}{l}\text { Antimicrobial, damage to microbial cell } \\
\text { membrane permeability and respiration. }\end{array}$ & E. coli & -- & 117 \\
\hline & $\begin{array}{l}\text { PVA/N-carboxymethyl } \\
\text { chitosan (fibrous sheet) }\end{array}$ & Antimicrobial & E. coli & -- & 118 \\
\hline & $\begin{array}{l}\text { Chitosan-hyaluronic } \\
\text { acid (sponges) }\end{array}$ & $\begin{array}{l}\text { Antimicrobial (silver ions inhibits } \\
\text { mitochondrial membrane potential } \\
\text { and respiratory chain) }\end{array}$ & $\begin{array}{l}\text { S. aureus, MRSA, } P \text {. } \\
\text { aeruginosa and } \\
\text { Klebsiella pneumonia }\end{array}$ & -- & 119 \\
\hline \multirow[t]{2}{*}{ Gold } & Chitosan (film) & $\begin{array}{l}\text { Stabilizing agent, antimicrobial cell wall } \\
\text { interaction and destabilization (dependent } \\
\text { on positive amine groups in chitosan). }\end{array}$ & $\begin{array}{l}\text { S. aureus and } P \text {. } \\
\text { aeurigensoa }\end{array}$ & -- & 120 \\
\hline & $\begin{array}{c}\text { Colloid / } \\
\text { Chitosan (film) }\end{array}$ & Higher keratinocyte proliferation & -- & -- & 121 \\
\hline \multirow[t]{2}{*}{ Copper } & $\begin{array}{c}\text { Chitosan } \\
\text { (Nanocomposite) }\end{array}$ & $\begin{array}{l}\text { Higher VEGF and TGF-b1- increased } \\
\text { Angiogenesis, fibroblast proliferation, and } \\
\text { collagen deposition. Lesser TNF-a and } \\
\text { IL-10-decreased inflammatory response. }\end{array}$ & -- & $\begin{array}{l}\text { Open excision } \\
\text { wound model } \\
\text { (male Wistar rats) }\end{array}$ & 122 \\
\hline & $\begin{array}{l}\text { Chitosan } \\
\text { (nanocomposite) }\end{array}$ & Antimicrobial & E. coli and S. aureus & -- & 123 \\
\hline \multirow[t]{2}{*}{$\mathrm{ZnO}$} & $\begin{array}{l}\text { Chitosan hydrogel } \\
\text { (composite bandages) }\end{array}$ & $\begin{array}{l}\text { Antimicrobial, improved reepithelialisation } \\
\text { and collagen deposition. }\end{array}$ & E. coli and S. aureus & $\begin{array}{l}\text { Open excision } \\
\text { wound model } \\
\text { (Sprague-Dawley) }\end{array}$ & 124 \\
\hline & $\begin{array}{l}\text { Alginate/Chitosan } \\
\text { (Sponges) }\end{array}$ & Antimicrobial & $\begin{array}{l}\text { E. coli, MRSA, S. aureus } \\
\text { and C. albicans }\end{array}$ & -- & 125 \\
\hline $\begin{array}{c}\mathrm{TiO}_{2} \\
\text { chitosan }\end{array}$ & $\begin{array}{l}\text { Collagen (Artificial } \\
\text { skin substitute) }\end{array}$ & $\begin{array}{c}\text { Bactericidal, immune } \\
\text { enhancing (TNF-a, IL-6). }\end{array}$ & -- & -- & 126 \\
\hline $\begin{array}{l}\text { Nanorods } \\
\text { of } \mathrm{TiO}_{2}\end{array}$ & $\begin{array}{l}\text { Chitosan, poly }(\mathrm{N}- \\
\text { vinylpyrrolidone) } \\
\text { (PVP) }\end{array}$ & $\begin{array}{l}\text { Antibacterial, N-acetylglucosamine, } \\
\text { from chitosan degradation Contributes } \\
\text { to fibroblast proliferation. }\end{array}$ & $\begin{array}{l}\text { E. coli, } S \text {. aureus, } \\
\text { P. aeruginosa, } \\
\text { and } B \text {. subtilis }\end{array}$ & $\begin{array}{l}\text { Open excision } \\
\text { type wounds } \\
\text { (Albino rat) }\end{array}$ & 127 \\
\hline $\mathrm{TiO}_{2}$ & $\begin{array}{l}\text { Chitosan-pectin } \\
\text { (Ternary dressing) }\end{array}$ & $\begin{array}{l}\text { Antibacterial, completely regenerated } \\
\text { wound with epidermis and Dermis. }\end{array}$ & $\begin{array}{c}\text { E. coli, } \\
\text { Staphylococcus aureus, } \\
\text { Pseudomonas aeruginosa, } \\
\text { B. subtilis, and A. niger }\end{array}$ & $\begin{array}{l}\text { Open excision } \\
\text { type wounds } \\
\text { (Albino rat) }\end{array}$ & 128 \\
\hline
\end{tabular}

Table 9 NPs and the targeted types of wound infection

\begin{tabular}{|c|c|c|}
\hline Types of nanomaterials & Targeted wounds & Ref. \\
\hline $\begin{array}{l}\text { Chitosan oligosaccharides } \\
\text { with Ag NPs and PVA }\end{array}$ & $\begin{array}{l}\text { Acts at as excellent antibacterial agent at the site of the } \\
\text { wound and does not possess any toxicity. }\end{array}$ & 145 \\
\hline Nanofibres associated with Ag NPs & $\begin{array}{l}\text { Helps in reducing inflammation at the surface } \\
\text { wounds and also promotes faster healing. }\end{array}$ & 146 \\
\hline Poly-(Lactic-co-glycolic acid)/silk fibroin & Helps in curing various types of diabetes associated wounds. & 147 \\
\hline PVA associated with chitosan & Used for treating the diabetes wounds within the rats. & 148 \\
\hline Ferric oxide nanoparticles & Helps in the regeneration of the surface wounds. & 149 \\
\hline Ag NPs within polyethylene clothes & Helps in faster regeneration of cutaneous wounds. & 150 \\
\hline
\end{tabular}

green synthesized nanomaterials. Antimicrobial, antioxidant and re-epithelialization have been proven to help enhancing regeneration. Therefore, drawing a conclusion, it would be fair enough to say that the nano-based treatment has wide scope, potential and diverse application in the field of medical science [50]. However, more extensive research, innovation and studies are required for better hold of the properties of these novel materials to use it for the betterment of mankind. 
It has been seen that microbial infection is the major cause that delays the natural healing process. Different species of bacteria such as E. coli, S. aureus etc. once get in touch with the wound, start consuming the tissues and forming dense colonies (or bacterial biofilms) if not maintained a proper sterile condition. This can cause severe infections that sometimes may lead to sacrifice of the organ. On other hand, fibroblast cells are critical for breaking down fibrin clot, creating extra cellular matrix (ECM) to support growth of collagen fibers and other essential cells related to wound healing. Hence, developing a system that has both the mentioned properties and that is compatible in an in-vivo system is very useful.

The various types of metallic and non-metallic nanoparticles has been chosen for therapeutic material mainly because of its biocompatibility. The knowledge of various approaches for the treatment helped to select the most effective and feasible way materializing the project. The green synthesis method has been chosen for its various biological advantages over the others and also for its cost effectiveness.

Hence, these nano-systems that the researchers are designing and developing for the successful treatment of wounds can revolutionize the future system of curing various types of wounds.

\section{References}

[1] S. Hamdan, I. Pastar, S. Drakulich, et al., Nanotechnologydriven therapeutic interventions in wound healing: potential uses and applications. ACS Central Science. 2017, 3(3): 163-175.

[2] C.K. Sen, Human wounds and its burden: an updated compendium of estimates. Advances in Wound Care. 2019, 8(2): 39-48.

[3] S.R. Nussbaum, M.J. Carter, C.E. Fife, et al., An economic evaluation of the impact, cost, and medicare policy implications of chronic nonhealing wounds. Value in Health. 2018, 21(1): 27-32.

[4] S.C. Wang, J. Anderson, R. Evans, et al., Point-ofcare wound visioning technology: Reproducibility and accuracy of a wound measurement app. PloS One, 2017, 12(8): e0183139.

[5] I. Pastar, O. Stojadinovic, N.C. Yin, et al., Tomic-Canic, M. Epithelialization in wound healing: a comprehensive review. Advances in Wound Care, 2014, 3(7): 445-464.

[6] S.A. Guo, L.A. DiPietro, Factors affecting wound healing. Journal of Dental Research. 2010, 89(3): 219-229.

[7] M. Loesche, S. E.Gardner, L. Kalan, et al., Temporal stability in chronic wound microbiota is associated with poor healing. Journal of Investigative Dermatology, 2017, 137: $237-244$

[8] C.L. Ventola, The antibiotic resistance crisis: part 1: causes and threats. P T. 2015, 40(4): 277-283.

[9] H. Nikaido, Multidrug resistance in bacteria. Annual Review of Biochemistry, 2015; 78: 119-146.
[10] D.G. Metcalf, P.G. Bowler, Biofilm delays wound healing: A review of the evidence. Burns \& Trauma, 2013, 1(1): 5-12.

[11] N.K. Rajendran, S.S.D. Kumar, N.N. Houreld, et al., A review on nanoparticle based treatment for wound healing. Journal of Drug Delivery Science and Technology, 2018; 44: 421-430.

[12] W. Wang, K. Lu, C. Yu, et al. Nano-drug delivery systems in wound treatment and skin regeneration. Journal of Nanobiotechnoly, 2019, 17: 82.

[13] M. Simões, M. Lemos, L.C. Simões, Phytochemicals against drug-resistant microbes. Dietary Phytochemicals and Microbes, 2012: 185-205.

[14] K.S. Akers, K. Mende, K.A. Cheatle, et al., Biofilms and persistent wound infections in United States military trauma patients: a case-control analysis. BMC Infectious Diseases. 2014, 14(1): 190.

[15] J.S. Weese A review of multidrug resistant surgical site infections. Veterinary and Comparative Orthopaedics and Traumatology, 2008, 21(01): 1-7.

[16] N.G. Forouhi, J. Luan, S. Hennings, et al., Incidence of Type 2 diabetes in England and its association with baseline impaired fasting glucose: the Ely study 1990 2000. Diabetic Medicine. 2007, 24(2): 200-207.

[17] H.A. Wallace, B.M. Basehore, and P.M. Zito, Wound healing phases. StatPearls Publishing, Treasure Island (FL), 2020.

[18] H.E. desJardins-Park, S. Mascharak, M.S. Chinta, et al., The spectrum of scarring in craniofacial wound repair. Frontiers in Physiology. 2019, 10: 322.

[19] C.L. Theoret, Update on wound repair. Clinical Techniques in Equine Practice, 2002, 3(2): 110-122.

[20] W. Wang, K.J. Lu, C.H. Yu, et al., Nano-drug delivery systems in wound treatment and skin regeneration. Journal of Nanobiotechnology, 2019, 17(1): 82.

[21] N. Mayet, Y.E. Choonara, P. Kumar, et al., A comprehensive review of advanced biopolymeric wound healing systems. Journal of Pharmaceutical Sciences, 2014, 103: 2211-2230.

[22] S. Das, A.B. Baker, Biomaterials and nanotherapeutics for enhancing skin wound healing. Frontiers in bioengineering and biotechnology, 2016, 4:82.

[23] A.T. Grazul-Bilska, M.L. Johnson, J.J. Bilski, et al., Wound healing: the role of growth factors. Drugs Today (Barc), 2003; 39(10): 787-800.

[24] S. Barrientos, O. Stojadinović, M.S. Golinko, et al., Growth factors and cytokines in wound healing. Wound repair and regeneration: official publication of the Wound Healing Society [and] the European Tissue Repair Society, 2008; 16(5): 585-601.

[25] J.W. Park, S.R. Hwang, I.S. Yoon. Advanced Growth Factor Delivery Systems in Wound Management and Skin Regeneration. Molecules. 2017, 22(8): 1259.

[26] N.K. Rajendran, S.S.D. Kumar, N.N. Houreld, et al., A review on nanoparticle based treatment for wound healing. Journal of Drug Delivery Science and Technology, 2018, 44: 421-430.

[27] M.M. Mihai, M.B. Dima, B. Dima, et al., Nanomaterials for Wound Healing and Infection Control. Materials, 2019; 12(13): 2176.

[28] T. Gunasekaran, T. Nigusse, M.D. Dhanaraju, Silver nanoparticles as real topical bullets for wound healing. Journal of the American college of clinical wound specialists, 2011, 3(4): 82-96.

[29] W. Boucher, J.M. Stern, V. Kotsinyan, Intravesical nanocrystalline silver decreases experimental bladder inflammation. Journal of Urology. 2008; 179: 1598-1602.

[30] C.R. Patra, R. Bhattacharya, E. Wang, Targeted delivery of gemcitabine to pancreatic adenocarcinoma using cetuximab as a targeting agent. Cancer Research. 2008; 
68: 1970-1978.

[31] J. Tian, K.K. Wong, C.M. Ho, et al., Topical delivery of silver nanoparticles promotes wound healing. Chem Med Chem. 2007, 2(1): 129-136.

[32] C. Fredriksson, G. Kratz, F. Huss, Accumulation of silver and delayed re-epithelialization in normal human skin: an ex-vivo study of different silver dressings. Wounds- $A$ Compendium of Clinical Research And Practice, 2009; 21(5): 116-123.

[33] M. Berthet, Y. Gauthier, C. Lacroix, et al., Nanoparticlebased dressing: the future of wound treatment? Trends in biotechnology, 2017; 35(8): 770-784.

[34] S.A. Chen, Topical treatment with anti-oxidants and $\mathrm{Au}$ nanoparticles promote healing of diabetic wound through receptor for advance glycation end-products. European Journal of Pharmaceutical Sciences, 2012; 47(5): 875883.

[35] S. Lu, D. Xia, G. Huang, et al.,Concentration e_ect of gold nanoparticles on proliferation of keratinocytes. Colloids Surf. B Biointerfaces 2010; 81(2): 406-411.

[36] T.J. Athauda, R.R. Ozer, J. M. Chalker, Investigation of cotton functionalized with $\mathrm{ZnO}$ nanorods and its interaction with E. coli, RSC Advances. 2013: 1066210665.

[37] M. Kaushik, R. Niranjan, R. Thangam, et al., Investigations on the antimicrobial activity and wound healing potential of $\mathrm{ZnO}$ nanoparticles. Applied Surface Science, 2019; 479: 1169-1177.

[38] C.P. Adams, K.A. Walker, S.O. Obare, et al., Sizedependent antimicrobial effects of novel palladium nanoparticles. PLoS One. 2014, 9(1): e85981.

[39] I.A. Shurygina, M.G. Shurygin Nanoparticles in wound healing and regeneration. InMetal Nanoparticles in Pharma, Springer, Cham, 2017, 21-37.

[40] M. Yamada, M. Foote, T.W. Prow, Therapeutic gold, silver, and platinum nanoparticles. Wiley Interdisciplinary Reviews: Nanomedicine and Nanobiotechnology. 2015, 7(3): 428-445.

[41] A.L. Ruiz, C.B. Garcia, S.N. Gallón, et al., Novel SilverPlatinum Nanoparticles for Anticancer and Antimicrobial Applications. International Journal of Nanomedicine. 2020, 15: 169.

[42] T. López-Goerne, P. Ramírez, D. Alvarez, et al.,Physicochemical properties and in vivo evaluation of $\mathrm{Pt} / \mathrm{TiO}_{2}-\mathrm{SiO}_{2}$ nanopowders. Nanomedicine. 2018, 13(17): 2171-2185.

[43] S. Alizadeh, B. Seyedalipour, S. Shafieyan, et al., Copper nanoparticles promote rapid wound healing in acute full thickness defect via acceleration of skin cell migration, proliferation, and neovascularization. Biochemical and biophysical research communications. 2019, 517(4): 684690.

[44] R. Tahvilian, M.M. Zangeneh, H. Falahi, et al., Green synthesis and chemical characterization of copper nanoparticles using Allium saralicum leaves and assessment of their cytotoxicity, antioxidant, antimicrobial, and cutaneous wound healing properties. Applied Organometallic Chemistry. 2019, 33(12): e5234.

[45] B. Tao, C. Lin, Y. Deng, et al., Copper-nanoparticleembedded hydrogel for killing bacteria and promoting wound healing with photothermal therapy. Journal of Materials Chemistry B. 2019, 7(15): 2534-2548.

[46] S. Pund, A. Joshi, Nanoarchitectures for Neglected Tropical Protozoal Diseases: Challenges and State of the Art. In Nano-and Microscale Drug Delivery Systems 2017: 439-480.

[47] J. Song, P. Zhang, L. Cheng, et al., Nano-silver in situ hybridized collagen scaffolds for regeneration of infected full-thickness burn skin. Journal of Materials Chemistry B, 2015: 4231-4241.
[48] R. Resmi, S. Unnikrishnan, L.K. Krishnan, et al., Synthesis and characterization of silver nanoparticle incorporated gelatin-hydroxypropyl methacrylate hydrogels for wound dressing applications. Journal of Applied Polymer Science, 2016, 134(10): 1-9.

[49] Z. Hussain, H.E. Thu, A. N. Shuid, Recent advances in polymer-based wound dressings for the treatment of diabetic foot ulcer: an overview of state-of-the-art. Current drug targets, 2018, 19(5): 527-550.

[50] K. Panasci, Burns and Wounds. Acute Care Handbook for Physical Therapists, 2013, 7: 283.

[51] E.A. Kamoun, E.R.S. Kenawy, X. Chen, A review on polymeric hydrogel membranes for wound dressing applications: PVA-based hydrogel dressings. Journal of advanced research, 2017; 8(3): 217-233.

[52] M.A. Mohammed, J. Syeda, K.M. Wasan, et al., An overview of chitosan nanoparticles and its application in non-parenteral drug delivery. Pharmaceutics, 2017; 9(4): 53.

[53] M. Hajialyani, D. Tewari, E. Sobarzo-Sánchez, et al., Natural product-based nanomedicines for wound healing purposes: therapeutic targets and drug delivery systems. International journal of nanomedicine, 2018; 13: 50235043.

[54] S.S.D. Kumar, Rajendran, N.K.N.N. Houreld, et al., H. Recent advances on silver nanoparticle and biopolymerbased biomaterials for wound healing applications. International journal of biological macromolecules, 2018; 115: 165-175.

[55] C. Holland, K. Numata, J. Rnjak-Kovacina, et al., The biomedical use of silk: Past, present, future. Advanced Healthcare Materials. 2019, 8(1): e1800465

[56] L. Bacakova, J. Pajorova, M. Zikmundova, et al., Nanofibrous scaffolds for skin tissue engineering and wound healing based on nature-derived polymers. Current and future aspects of nanomedicine. IntechOpen, 2019.

[57] H. Zhang, J. Xia, X. Pang, et al., Magnetic nanoparticleloaded electrospun polymeric nanofibers for tissue engineering. Materials Science and Engineering: C, 2017, 73: 537-543.

[58] L. Sun, W. Gao, and X. Fu, Enhanced wound healing in diabetic rats by nanofibrous scaffolds mimicking the basketweave pattern of collagen fibrils in native skin. Biomaterials Science, 2018, 6(2): 340-349.

[59] S. Hamdan, I. Pastar, S. Drakulich, et al., Nanotechnologydriven therapeutic interventions in wound healing: Potential uses and applications. ACS Central Science, 2017, 3(3): 163-175.

[60] R. Jangde, D. Singh, Preparation and optimization of quercetin-loaded liposomes for wound healing, using response surface methodology. Artificial Cells, Nanomedicine, and Biotechnology, 2016, 44(2): 635-641.

[61] N. Kianvash, A. Bahador, M. Pourhajibagher et al., Evaluation of propylene glycol nanoliposomes containing curcumin on burn wound model in rat: biocompatibility, wound healing, and anti-bacterial effects. Drug Delivery and Translational Research, 2017, 7(5): 654-663.

[62] H.L. Xu, P.P. Chen, D.L. ZhuGe, et al., Liposomes with silk fibroin hydrogel core to stabilize bFGF and promote the wound healing of mice with deep second-degree scald. Adv Healthc Mater, 2017, 6: 1700344.

[63] Z. Li, M. Liu, H. Wang, et al., Increased cutaneous wound healing effect of biodegradable liposomes containing madecassoside: preparation optimization, in vitro dermal permeation, and in vivo bioevaluation. International Journal of Nanomedicine, 2016, 11: 2995-3007.

[64] H.H. Homann, O. Rosbach, and W. Moll, A liposome hydrogel with polyvinyl-pyrrolidone iodine in the local treatment of partial-thickness burn wounds. Annals of Plastic Surgery, 2007, 59(4): 423-427. 
[65] N. Seyhan Evaluation of the healing effects of Hypericum perforatum and curcumin on burn wounds in rats. Evidence-Based Complementary and Alternative Medicine, 2020: 6462956.

[66] K. Reimer, P.M. Vogt, B. Broegmann, et al., An innovative topical drug formulation for wound healing and infection treatment: in vitro and in vivo investigations of a povidone-iodine liposome hydrogel. Dermatology. 2000, 201(3): 235-241.

[67] F. Roesken, E. Uhl, S.B Curri, et al., Acceleration of wound healing by topical drug delivery via liposomes. Langenbeck's Archives of Surgery, 2000, 385(1): 42-49.

[68] M.D. Cui, Z.H. Pan, and L.Q. Pan, Danggui Buxue extract-loaded liposomes in thermosensitive gel enhance in vivo dermal wound healing via activation of the VEGF/ $\mathrm{PI} 3 \mathrm{~K} / \mathrm{Akt}$ and TGF- $\beta /$ Smads signaling pathway. EvidenceBased Complementary and Alternative Medicine. 2017: 8407249.

[69] T. Mengoni, M. Adrian, S. Pereira, et al., A Chitosan - Based Liposome Formulation Enhances the In Vitro Wound Healing Efficacy of Substance P Neuropeptide. Pharmaceutics. 2017, 9(4): 56.

[70] S. Chhibber, J. Kaur, S. Kaur, Liposome entrapment of bacteriophages improves wound healing in a diabetic mouse MRSA infection. Frontiers in microbiology. 2018, 9: 561.

[71] D.J. Dev, J.S. Jayaprakash, P.K. Kulkarni, et al.,Formulation and evaluation of different topical dosage forms for wound healing properties. International Journal of Research in Pharmaceutical Sciences. 2020, 11(1): 730-746.

[72] P.S. Nunes, A.S. Rabelo, J.C. de Souza, et al., Gelatinbased membrane containing usnic acid-loaded liposome improves dermal burn healing in a porcine model. International journal of pharmaceutics. 2016, 513(1-2): 473-482.

[73] K. Bankoti, A.P. Rameshbabu, S. Datta, et al., Onion derived carbon nanodots for live cell imaging and accelerated skin wound healing. Journal of Materials Chemistry B, 2017; 5(32): 6579-6592.

[74] C. Zhu, Y. Fu, C. Liu, et al., Carbon Dots as Fillers Inducing Healing/Self - Healing and Anticorrosion Properties in Polymers. Advanced Materials, 2017; 29(32): 1701399.

[75] S. Quignard, T. Coradin, J. J. Powell, et al., Silica nanoparticles as sources of silicic acid favoring wound healing in vitro. Colloids and Surfaces B: Biointerfaces, 2017; 55: 530-537.

[76] M. Tiwari, K. Narayanan, M. B. Thakar, et al., Biosynthesis and wound healing activity of copper nanoparticles. IET nanobiotechnology, 2014; 8(4): 230237.

[77] D. Lahiri, S. Dash, R. Dutta, et al., Elucidating the effect of anti-biofilm activity of bioactive compounds extracted from plants. Journal of biosciences, 2019; 44(2): 52.

[78] N. Roy, M. Agrawal, S. Chaudhary, et al., Review article on permeation enhancers: a major breakthrough in drug delivery technology. International Journal of Pharmaceutical Sciences and Research. 2017; 8(3): 1001.

[79] P.S. Chauhan, V.I. Shrivastava, G.B. Prasad, et al., Effect of Silver Nanoparticle-Mediated Wound Therapy on Biochemical, Hematological, and Histological Parameters. APCR. 2018, 11(3): 251-258.

[80] V. Dhapte, S. Kadam, A. Moghe, et al., Probing the wound healing potential of biogenic silver nanoparticles. Journal of wound care. 2014, 23(9): 431-441.

[81] E.Y. Ahn, H. Jin, Y. Park, Assessing the antioxidant, cytotoxic, apoptotic and wound healing properties of silver nanoparticles green-synthesized by plant extracts. Materials Science and Engineering: C. 2019, 101: 204-
216.

[82] A. Ahmeda, N. Abbasi, H. Ghaneialvar, et al., Application of titanium nanoparticles containing natural compounds in cutaneous wound healing. Applied Organometallic Chemistry, 2020, 34(4): e5480.

[83] T. Shanmugasundaram, M. Radhakrishnan, V. Gopikrishnan, et al., In vitro antimicrobial and in vivo wound healing effect of actinobacterially synthesised nanoparticles of silver, gold and their alloy. RSC advances. 2017, 7(81): 51729-51743.

[84] W. Czaja, D. Romanovicz, and R.M. Brown, Structural Investigations of Microbial Cellulose Produced in Stationary and Agitated Culture. Cellulose. 2004, 11(3/4): 403-411.

[85] Y.H. Kim, Y.S. Kang, Synthesis and characterization of $\mathrm{Ag}$ nanoparticles, $\mathrm{Ag}-\mathrm{TiO}_{2}$ nanoparticles and $\mathrm{Ag}-\mathrm{TiO}_{2}-$ chitosan complex and their application to antibiosis and deodorization. Materials Research Society. 2004, 820: 161-166.

[86] S. Yamanaka, K. Watanabe, N. Kitamura, et al. The Structure and mechanical properties of sheets prepared from bacterial cellulose. J Mater Sci. 1989, 24(9): 31413144.

[87] M. Iguchi, S. Yamanaka, A. Budhiono, Bacterial cellulose a masterpiece of nature's arts. J Mater Sci. 2000, 35(2): 261-270

[88] M. Griffith, Anti-microbiological and anti-infective activities of silver. In Silver nanoparticle applications: In the fabrication and design of medical and biosensing devices. Springer, 2015: 127-146,

[89] R.Y. Pelgrift, A.J. Friedman, Nanotechnology as a therapeutic tool to combat microbial resistance. Advanced Drug Delivery Reviews. 2013, 65(13-14): 1803-1815.

[90] K. Chaloupka, Y. Malam, and A.M. Seifalian, Nanosilver as a new generation of nanoproduct in biomedical applications. Trends in Biotechnology, 2010, 28(11): 580588.

[91] G. Baier, A. Cavallaro, K. Friedemann, Enzymatic degradation of poly (l-lactide) nanoparticles followed by the release of octenidine and their bactericidal effects. Nanomedicine: Nanotechnology, Biology and Medicine. 2014, 10(1): 131-139.

[92] H. Liu, Y. Guan, D. Wei, et al., Reinforcement of injectable calcium phosphate cement by gelatinized starches. Journal of Biomedical Materials Research Part B: Applied Biomaterials. 2016, 104(3): 615-625.

[93] K.K. Chereddy, C.H. Her, M. Comune, PLGA nanoparticles loaded with host defense peptide LL37 promote wound healing. Journal of Controlled Release. 2014, 194: 138-147.

[94] K.K. Chereddy, A .Lopes, S. Koussoroplis, et al., Combined effects of PLGA and vascular endothelial growth factor promote the healing of non-diabetic and diabetic wounds. Nanomedicine: Nanotechnology, Biology and Medicine. 2015, 11(8): 1975-1984.

[95] K.K. Chereddy, R. Coco, P.B. Memvanga, et al., Combined effect of PLGA and curcumin on wound healing activity. Journal of Controlled Release. 2013, 171(2): 208-215.

[96] H. Nurhasni, J. Cao, M. Choi, et al., Nitric oxidereleasing poly (lactic-co-glycolic acid)-polyethylenimine nanoparticles for prolonged nitric oxide release, antibacterial efficacy, and in vivo wound healing activity. International Journal of Nanomedicine. 2015, 10: 3065.

[97] Z. Xie, Dual growth factor releasing multi-functional nanofibers for wound healing. Acta Biomater. 2013, 9: 9351-9359

[98] W.G. La, H.S. Yang, Heparin-Conjugated Poly (LacticCo-Glycolic Acid) Nanospheres Enhance Large-Wound Healing by Delivering Growth Factors in Platelet-Rich Plasma. Artificial Organs. 2015, 39(4): 388-394. 
[99] Z. Hussain, H. Katas, M.C. Amin, et al., Antidermatitic perspective of hydrocortisone as chitosan nanocarriers: an ex vivo and in vivo assessment using an NC/Nga mouse model. Journal of Pharmaceutical Sciences. 2013, 102(3): 1063-1075.

[100] I.C. Külkamp-Guerreiro, M.N. Souza, M.D. Bianchin, et al., Evaluation of lipoic acid topical application on rats skin wound healing. Acta Cirurgica Brasileira. 2013, 28(10): 708-715.

[101] E. Moreno, J. Schwartz, E. Larrea, et al. Assessment of $\beta$-lapachone loaded in lecithin-chitosan nanoparticles for the topical treatment of cutaneous leishmaniasis in L. major infected BALB/c mice. Nanomedicine: Nanotechnology, Biology and Medicine. 2015, 11(8): 2003-2012.

[102] Y.H. Lin, J.H. Lin, Y.S. Hong, Development of chitosan/ poly- $\gamma$-glutamic acid/pluronic/curcumin nanoparticles in chitosan dressings for wound regeneration. Journal of Biomedical Materials Research Part B: Applied Biomaterials. 2017, 105(1): 81-90.

[103] Y.H. Lin, J.H. Lin, T.S. Li, et al., Dressing with epigallocatechin gallate nanoparticles for wound regeneration. Wound Repair and Regeneration. 2016, 24(2): 287-301.

[104] M. Ahmadi, M. Adibhesami, The Effect of Silver Nanoparticles on Wounds Contaminated with Pseudomonas aeruginosa in Mice: An Experimental Study. Iranian Journal of Pharmaceutical Research. 2017, 16: 661-669.

[105] S. Pal, R. Nisi, M. Stoppa, et al., Silver-functionalized bacterial cellulose as antibacterial membrane for woundhealing applications. ACS Omega, 2017, 2: 3632-3639.

[106] M. Radulescu, E. Andronescu, and G. Dolete, Silver nanocoatings for reducing the exogenous microbial colonization of wound dressings. Materials, 2016, 9(5): 345.

[107] S. Marza, K. Magyari, Skin wound regeneration with bioactive glass-gold nanoparticles ointment. Biomedical Materials. 2019, 14: 025011.

[108] Z. Boroumand, N. Golmakani, S. Boroumand, Clinical trials on silver nanoparticles for wound healing. Nanomedicine Journal, 2018, 5: 186-191

[109] V. Vijayakumar, S.K. Samal, S. Mohanty, et al., Recent advancements in biopolymer and metal nanoparticlebased materials in diabetic wound healing management. Int. J. Biol. Macromol., 2019, 122: 137-148.

[110] R. Szmyd, A.G. Goralczyk, L. Skalniak, et al., Effect of silver nanoparticles on human primary keratinocytes. Biol. Chem., 2013, 394: 113-123.

[111] M. Ahmadi, M. Adibhesami, The effect of silver nanoparticles on wounds contaminated with Pseudomonas aeruginosa in mice: An experimental study. Iran. J. Pharm. Res., 2017, 16: 661-669.

[112] A. Mohandas, S. Deepthi, R. Biswas, et al., Chitosan based metallic nanocomposite scaffolds as antimicrobial wound dressings. Bioact Mater., 2017, 3(3): 267-277.

[113] R. Arshad, M.F. Sohail, H.S. Sarwar, et al., ZnONPs embedded biodegradable thiolated bandage for postoperative surgical site infection: In vitro and in vivo evaluation. PloS One, 2019, 14(6): e0217079.

[114] P.M. Arockianathan, S. Sekar, B. Kumaran, et al., Preparation, characterization and evaluation of biocomposite films containing chitosan and sago starch impregnated with silver nanoparticles. International Journal of Biological Macromolecules, 2012, 50(4): 939946.

[115] M. Pérez-Díaz, E. Alvarado-Gomez, M. Magaña-Aquino, et al., Anti-biofilm activity of chitosan gels formulated with silver nanoparticles and their cytotoxic effect on human fibroblasts. Materials Science and Engineering: C,
60: 317-323.

[116] R. Srivastava, D.K. Tiwari, and P.K. Dutta, 4-(Ethoxycarbonyl) phenyl-1-amino-oxobutanoic acid-chitosan complex as a new matrix for silver nanocomposite film: Preparation, characterization and antibacterial activity. International Journal of Biological Macromolecules, 2011, 49(5): 863-870.

[117] A.M. Abdelgawad, S.M. Hudson, and O.J. Rojas, Antimicrobial wound dressing nanofiber mats from multicomponent (chitosan/silver-NPs/polyvinyl alcohol) systems. Carbohydrate Polymers, 2014, 100: 166-178.

[118] F. Pishbin, V. Mourino, J.B. Gilchrist, et al., Single-step electrochemical deposition of antimicrobial orthopaedic coatings based on a bioactive glass/chitosan /nano-silver composite system. Acta Biomaterialia, 2013, 9(7): 74697479 .

[119] B.S. Anisha, R. Biswas, K.P. Chennazhi, et al., Chitosanhyaluronic acid/nano silver composite sponges for drug resistant bacteria infected diabetic wounds. International Journal of Biological Macromolecules, 2013, 62: 310320.

[120] A. Regiel-Futyra, M. Kus-Liśkiewicz, and V. Sebastian, Development of noncytotoxic chitosan-gold nanocomposites as efficient antibacterial materials. ACS Applied Materials \& Interfaces. 2015, 7(2): 1087-1099.

[121] Y. Zhang, H. He, W.J. Gao, et al., Rapid adhesion and proliferation of keratinocytes on the gold colloid/chitosan film scaffold. Materials Science and Engineering: $C$. 2009, 29(3): 908-912.

[122] A. Gopal, V. Kant, A. Gopalakrishnan, et al., Chitosanbased copper nanocomposite accelerates healing in excision wound model in rats. European journal of pharmacology. 2014, 731: 8-19.

[123] G. Borkow, J. Gabbay, R. Dardik, et al., Molecular mechanisms of enhanced wound healing by copper oxideimpregnated dressings. Wound repair and regeneration. 2010, 18(2): 266-275.

[124] R. Wahab, A. Mishra, S.I. Yun, et al., Fabrication, growth mechanism and antibacterial activity of $\mathrm{ZnO}$ microspheres prepared via solution process. Biomass and Bioenergy. 2012, 39: 227-236.

[125] P.T. Sudheesh Kumar, V.K. Lakshmanan, T.V. Anilkumar, et al., Flexible and microporous chitosan hydrogel/nano $\mathrm{ZnO}$ composite bandages for wound dressing: in vitro and in vivo evaluation. ACS Applied Materials \& Interfaces, 2012, 4(5): 2618-2629.

[126] C.C. Peng, M.H. Yang, W.T. Chiu, et al., Composite nano-titanium oxide-chitosan artificial skin exhibits strong wound-healing effect - an approach with anti inflammatory and bactericidal kinetics. Macromolecular Bioscience, 2008, 8(4): 316-327.

[127] D. Archana, J. Dutta, P.K. Dutta, Evaluation of chitosan nano dressing for wound healing: Characterization, in vitro and in vivo studies. International Journal of Biological Macromolecules. 2013, 57: 193-203.

[128] A.A. Madhavan, A. Mohandas, A. Licciulli, et al., Electrospun continuous nanofibers based on a $\mathrm{TiO}_{2}-\mathrm{ZnO}-$ graphene composite. RSC Advances, 2013, 3(47): 2531225316.

[129] G.A. Seisenbaeva, K. Fromell, V.V. Vinogradov, et al., Dispersion of $\mathrm{TiO}_{2}$ nanoparticles improves burn wound healing and tissue regeneration through specific interaction with blood serum proteins. Scientific Reports, 2018, 8(1): 1-2.

[130] F. Oyarzun-Ampuero, A. Vidal, and M. Concha, Nanoparticles for the treatment of wounds. Current Pharmaceutical Design, 2015, 21(29): 4329-4341.

[131] A.M. Fayaz, K. Balaji, M. Girilal, et al., Biogenic synthesis of silver nanoparticles and their synergistic effect with antibiotics: A study against gram-positive and 
gram-negative bacteria. Nanomedicine, 2010, 6: 103-109.

[132] S. Hamdan, I. Pastar, S. Drakulich, et al., Nanotechnologydriven therapeutic interventions in wound healing: Potential uses and applications. ACS Central Science, 2017, 3: 163-175.

[133] R. Jayakumar, M. Prabaharan, and P.T. Sudheesh Kumar, Biomaterials based on chitin and chitosan in wound dressing applications. Biotechnology Advances, 2011, 29: 322-337.

[134] O. Akturk, K. Kismet, A.C. Yasti, et al., Collagen / gold nanoparticle nanocomposites: A potential skin wound healing biomaterial. Journal of Biomaterials Applications 2016, 31: 283-301.

[135] M. Tiwari, K. Narayanan, M.B. Thakar, et al., Biosynthesis and wound healing activity of copper nanoparticles. IET Nanobiotechnol. 2014, 8: 230-237

[136] C. Zgheib, S.A. Hilton, L.C. Dewberry, et al. Use of cerium oxide nanoparticles conjugated with microRNA146a to correct the diabetic wound healing impairment. Journal of the American College of Surgeons, 2019, 228(1): 107-115.

[137] A. K. Barui, V. Veeriah; S. Mukherjee, et al., Zinc oxide nanoflowers make new blood vessels. Nanoscale, 2012, 4: 7861-7869.

[138] M. Li, F. Li, and T. Wang, Fabrication of carboxymethylcellulose hydrogel containing $\beta$-cyclodextrin-eugenol inclusion complexes for promoting diabetic wound healing. Journal of Biomaterials Applications, 2020, 34(6): 851-863.

[139] E.M. Hetrick, J.H. Shin, H.S. Paul, et al., Anti-biofilm efficacy of nitric oxide-releasing silica nanoparticles. Biomaterials, 2009, 30(14): 2782-2789.

[140] S.K. Nethi, S. Das, C.R. Patra, et al., Recent advances in inorganic nanomaterials for wound-healing applications. Biomaterials Science. 2019, 7(7): 2652-2674.

[141] S. Chigurupati, M.R. Mughal, E. Okun, et al., Effects of cerium oxide nanoparticles on the growth of keratinocytes, fibroblasts and vascular endothelial cells in cutaneous wound healing. Biomaterials. 2013, 34(9): 2194-2201.

[142] C. Zgheib, S.A. Hilton, L.C. Dewberry, et al., Use of cerium oxide nanoparticles conjugated with microRNA146a to correct the diabetic wound healing impairment.
Journal of the American College of Surgeons, 2019, 228(1): 107-115.

[143] A. Nikpasand, M.R. Parvizi, Evaluation of the effect of titatnium dioxide nanoparticles/gelatin composite on infected skin wound healing; An animal model study. Bulletin of Emergency and Trauma. 2019, 7(4): 366-372.

[144] D. Archana, J. Dutta, and P.K. Dutta, Evaluation of chitosan nano dressing for wound healing: characterization, in vitro and in vivo studies. International Journal of Biological Macromolecules. 2013, 57: 193203.

[145] L. Lu, R. Fu, C. Li, et al., Silver nanoparticle/chitosan oligosaccharide/poly(vinyl alcohol) nanofibers as wound dressings: A preclinical study. International Journal of Nanomedicine, 2013, 8: 4131-4145

[146] R. Dong, Y. Jia, C.C. Qin, et al., In situ deposition of a personalized nanofibrous dressing via a handy electrospinning device for skin wound care. Nanoscale, 2016, 8: 3482-3488.

[147] S. Shahverdi, M. Hajimiri, M.A. Esfandiari, et al., Fabrication and structure analysis of poly(lactideco-glycolic acid)/silk fibroin hybrid scaffold for wound dressing applications. International Journal of Pharmaceutics, 2014, 473: 345-355.

[148] A. Gholipour-Kanani, S.H. Bahrami, and S. Rabbani, Effect of novel blend nanofibrous scaffolds on diabetic wounds healing. IET Nanobiotechnology, 2016, 10: 1-7

[149] I. Anghel, A.M. Holban, A.M. Grumezescu, et al., Modified wound dressing with phyto-nanostructured coating to prevent staphylococcal and pseudomonal biofilm development. Nanoscale Research Letters, 2012, 7(1): 690

[150] C. Rigo, L. Ferroni, I. Tocco, et al., Active silver nanoparticles for wound healing. International Journal of Molecular Sciences, 2013, 14: 4817-4840.

Copyright $\subseteq$ Moupriya Nag, Dibyajit Lahiri, Sudipta Dash, Sayantani Garai, Dipro Mukherjee, Ritwik Banerjee, and Rina Rani Ray. This is an open-access article distributed under the terms of the Creative Commons Attribution License, which permits unrestricted use, distribution, and reproduction in any medium, provided the original author and source are credited. 